
$N \times V=$

25

$(g)$

Q

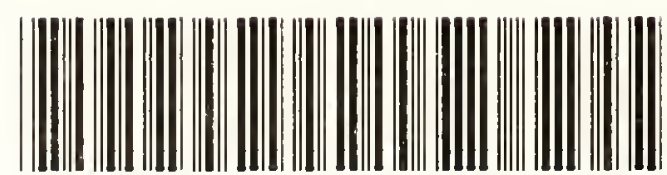

22101097371 
Digitized by the Internet Archive in 2017 with funding from Wellcome Library

https://archive.org/details/b29826603 



\section{THE DIVINE ORIGIN OF THE CRAFT OF THE HERBALIST}





\title{
THE DIVINE ORIGIN OF THE CRAFT OF THE HERBALIST
}

BY

SIR E. A. WALLIS BUDGE, $\mathbf{K}_{\text {T. }}$

M.r., Litr.D. Cambridge), M.A., D. L.itT. Oxford), D.L.r. (Durham), I.S.A. SOMÉTIF, IEEPIR OF EGSPTIAN AND ASSYRIAX ANTIGCITIES, BRITISII MUSELM; CORRLSPONDIXG MEMBER OF TIL ACADEMY OF SCIENCES, LISBON; AND CORRESPOXDIN, MEMHER OL THE PIHLOSOPHICAL, SOCIFTY OF AMERICA

WITII TIIRTEEN ILLUSTRATIONS

\author{
PUBLISHED AT \\ CULPEPER HOUSE \\ BY THE SOGIETY OF HERBALISTS \\ 7 BAKER STREET, LONDON, W. \\ 1928 \\ [All rights reservel]
}


Printed in Great Britaln by richard Clay \& Suns, limtiled, BUSigar, SUHULK.

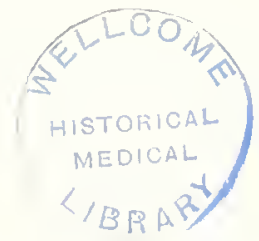




\section{PREFATORY NOTE}

Tine herb-doctors and phrsicians of Sumer, Babylon, Assyria and Egypt have proclatimed with no uncertain roice that their craft was founded by the gods, who taught men the curative properties of water, herbs and plants and oils, and who were themselves the first practitioners. And for the last 5000 years men in every civilized comntry have regarded the divine art of healing as the greatest of the gods' gifts to men. 'The divine art was carefully and jealously guarded by its recipients, and for many generations was preserved by means of oral tradition. As soon as men learned to write they committed the teaching to the clay tablet and the roll of papyrus, and drew up lists of medicinal herbs, and these documents constituted the first Herbals. The British Pharnacopoeia of the present day contains much that is derived from the carly Oricntal Herbals.

It would be foolish to blink the fact that in ancient Ilerbals medicine and magic are almost inextricably mixed together; but the broad fact remains, and it is admitted by all competent authorities, that the compilers of the oldest Oriental Iists of Plants and Incrbals had a very real knowledge of prinitive medicine. But for the ingrained and invincible love of magie in their patients that knowledge would 
hare been greater. From this real knowledge the modern science of herbalism has becn developed, just as astronomy owes its origin to Sumerian and Babylonian astrology, and chemistry to alchemy, i.c. "the art of Egypt" (.11, the Arabic article. Xipeia).or" "the art of the land of black carth" (Xquia).

The Edwin Smith Papyrus affords eridence that in berpt at least there were as carly as B.C. 2000 herb-doctors and physicians who discarded magic from their treatment of patients, and who understood that sicknesses and discases were the effects, not of the operations of devils, but of purcly natural causes. They practised dissection, and tricd to find what these causes were, and the passages of the papyrus already published certainly suggest that such men were genuine seckers after truth, who were as much interested in informing themselves as in helping their patients.

The Asu, or Oriental prototype of the physician, whether Babylonian or Egyptian of to-day wore a long woollen cloak, and a head cloth in folds. and sandals; when he set out on his rounds he probably rode a donkey. As a herbalist he took with him his box of medicines, and as a magician his wonderworking rod, which was the symbol of his profession. This last was a very important object. and its use among magicians was general. With the rod which was cndowed with the power of tuming into a serpent, and which God had given to him (kxod. iv. 17), Moses divided the waters al the Sea of Reeds (bxod. ir. 21). and defeated Amalck (Exod. xrii. 11), and bromeht water ont of the rock. Ind Aaron with his rod tmoned the waters of the Nile inte blood. and produced the plagence of froms (Exod. vii. 19: viii. (j). 
The Sumerian herbalist was accompanied by two men, one to recite ineantations orer the patient (the exoreist), and the other to interpret the omens derived from his condition. The herbalist was the least important of the three, for the divine art of the herb-doctor, strange though it seems, was at that time in thrall to magic, and the herb-doctor himself was subordinate to the exorcist and the interpreter of omens. To-day the physician visits his patients by motor-car, without enchanter and without a reader of omens, for he and his craft are now freed from the bonds of magie. Armed with the true science of medicine, he takes no wonder-working rod with him. But he and his colleagues, like their great predecessor Esculapius, preserve the memory of and pay honour to the serpent-encircled rod of the Sumerian god Ningishzida, the son of Ninazu, the Master-physician, by making it the symbol of their great profession.

During the past forty years a great deal has been discorered about the forms and eontents of Oriental Herbals, but the information given about them in the ordinary text-books is meagre and ineomplete. And during the long period when I was Keeper of Egyptian and Assyrian Antiquities in the British Museum I was often called upon to supplement it. I have, therefore, at the request of my friends in the Society of Herbalists, written the following pages on the earliest Oriental Herbals strictly, of course, from the point of view of the archacologist, and described briefly the attributes and works of the earliest gods of medicine in Mesopotamia and Egypt. I have tried to show how the Sumerian, Eyptian, Babylonian and Assyrian IIerbals formed the foundation of the Greek Herbals, and how these in turn were transtated into syriac 
and Irabic and so becance known thromghout Western Isia. and. thanks to the Nestorian missionaly doctons, in 'lurkestan and (hina also. For information about the transmission of the IIerbats of loiosoroides and Galen into burope by mans of translations into Iatin. Italian, German, Fench. Spanish. Anglosaxom. etc.. the reader must comsult the usual nuclical Bibliographies. 'The literary history of the English IIerbal has been treated in a competent manner by Miss Eleanour Sinclair Rohde in her Old English Herhals. I condon, 1920, and by Mrs. C. H. I Ieyel in her admilable book 'The Magic of Herbs. I ondon, 1926.

The illustrations have been made from photographs of mamscripts in the British Muscum by permission of the 'Trustes. "The drawing of the serpent-encircled stall. which is, no doubt, the original of the serpentcucircled stares of Escoulapius and Iyoicia, is reproAnced from Ineuzey, Catalogue des Intiquités C'haldéennes, Paris, 1902, p. 280. 'The vase of Guclea, whence the whole scene is taken, is published in De Sarzec, Découcortes, Pl. 4i3, fig. …

Is Blommstmery strect.

\section{F. 1. WaLLIS BLDGE.}

Berlford siquare.

lomedon. "I'.C. 1.

Norember 


\section{CONTENTS}

PHEFTTOE NOTE - V

I. THL: (1L1) GOHS AS IIERBALSTS AND THEIR DIVINE

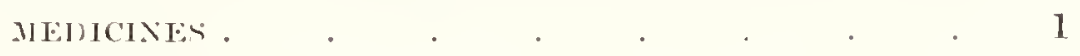

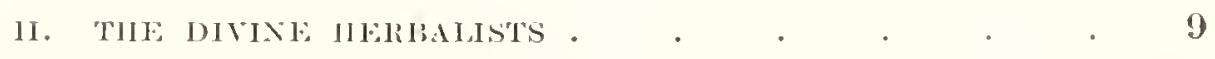

II. WATLR A ININE ELLMENT . . . . . 20

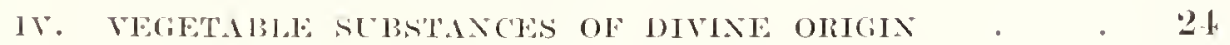

V. ANCIENT LOMPTIN IIERBALS AND BOOKS OF MEDICINE 26

VI. HOLY OLLS ANI MEDICATED UNGUENTS . . . 29

Vl1. SUMERIAN ANH ASSYRIAN UERBALS . . . . 36

VII. THE, GREEK IIERMALS . . . . . . 54

1x. THL: Latix IHERBAL . . . . . . 67

X. THE HERLAL IN SYLIAC. . . T0

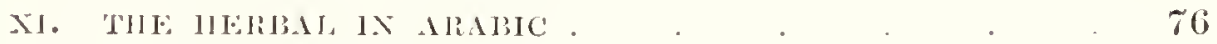

xil. COPTIC LASTS OF PLANTS . . . . . 69

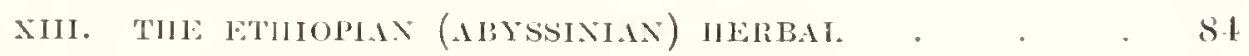

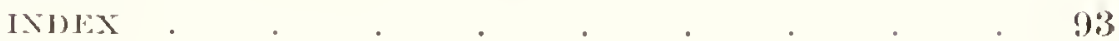





\section{LIST OF ILLUSTRATIONS}

PAGE

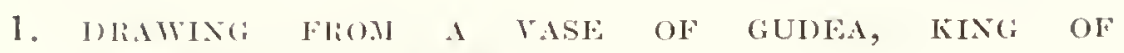
B.ABY1.0NIA, H.C. 2350 . . . . . . 15

2, 3. TRAXACRIPL OF TWO PRESCRLPTIONS IN THE EBERS PAPYlis . . . . . . . . . . . 34,35

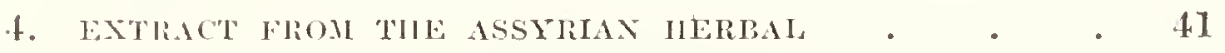

5. 6. LIST OF PlaNTS IN TIE HERB-GARDEN OF

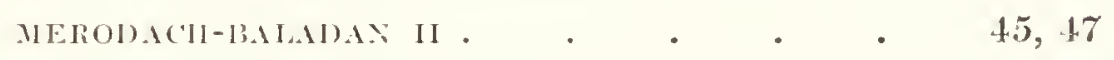

7. FACSIMIL: OF A PAGT OF TIIE IIERIAL OF DIOSCORIDES IX GIIEKK

S. FACSIMIL OF A PACE OF TIL IIERBAL OF IDOSCORIDES

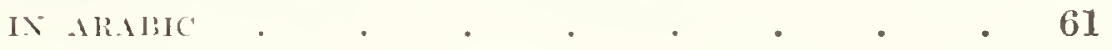

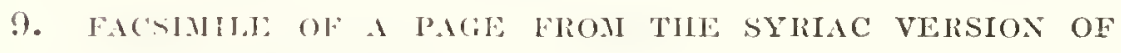
GALEX'S IHERBAL • • • • • • • 71

10. FACSIMLA: OF 1 PAGE OF A COPTIC LIST OF PLANTS - S1

11. FACSIMIIE OF A COLUMA FROA AN ETIIOPIC IIERBAL 85

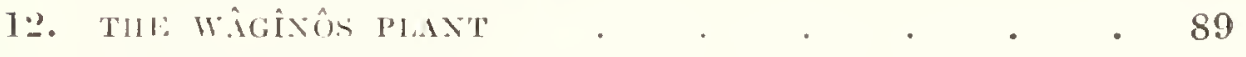

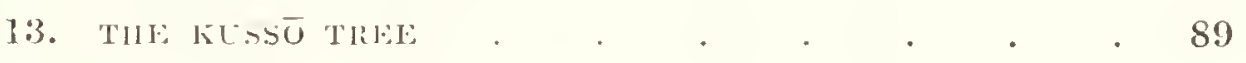


"And the Lord Gork planted a garden castward in kiden." Gis. ii. s.

". The Lorel hath created medicines out of the earth."

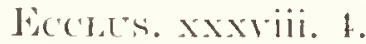

"If causeth herbs to grow for the serviee of man." PSilly cir. 1 t.

"Then give place to the healer, the Iord created him." Eccles. xxxiii. 12. 


\title{
THE DIVINE ORIGIN OF THE CRAFT OF THE HERBALIST
}

\author{
I \\ TIL OLI) GODS AS HERBALISTS AND TILEIR \\ DIVINE MEDICINES
}

Tre rehigious and magical writings of the great nations of antiquity, that is to say, the Chinese and the Indians, the Sumerians and Babylonians, the Persians and Assyrians (or, as we may now call them, the Akkadians), and the Egyptians and Nubians, contain abundant evidence that these primitive peoples believed that the first beings who possessed a knowledge of plants and their healing properties were the gods themselves. 'They further thought that the substances of plants were parts and pareels of the substances of which the persons of the gods were composed, and that the juices of plants were exudations or effluxes from them likewise. Some of the ancients thought that certain curative plants and herbs contained portions of the souls or spirits of the gods and spirits that were benevolent to man, and that poisonous plants were the abodes of evil spirits that were hostile to the Creator-inasmuch as they destroyed His handiwork, man-and to man and beast.

The oldest gods were too remote from the trivial aflairs of the daily life of men to prevent accidents and calamities from orertaking them, but they placed 
in the hands of their vicars upon earth a certain kind of knowledge and power which, if rightly used, would enable them to annul and destroy the machinations of evil spirits, and bring to nought the works effected by them, and even to alter the courses of natural phenomena in heaven and upon earth. 'To this knowledge and power the unsatisfactory name of "Magic" has been given, and though primarily the word "Magic" only described the learning of the priests and sages of the Medes and Persians, who were famed for their skill in working cnchantments, the word is now used to describe any supposed supernatural art, but more particularly any system of learning or art which claims to control the actions of spiritual or superhuman beings. "Magic" has always appealed greatly to men of all nations, for by the use of it a man ceases to be a supplicant of the gods, and is able to command and to force supernatural beings and things to do his will.

When the gods transmitted the knowledge of plants and their medical properties to their priests, they intended that knowledge to be used for the benefit of their worshippers, whether they were rich or poor, gentle or simple. What the priests had obtained from the gods was not "Magie," or "Natural Magice," but Natural Wisdom, and it was only because those who were treated by the priests did not understand even the rudiments of that wiston, that they regarded it as "magic" and ralled it so. As time went on those who applied this natural wistom to the relief of suffering humanity nuanified their oflice. and introduced into their operations incantations, divinations, astrology and at a later period alchemy. In lacet the medical magic of the oklest period represented 
a confused mass of belief's and practices which, because they were beyond the ordinary views of cause and effect, were regarded as supernatural. In all ages there have been minds which wore not satislied with the facts and explanations afforded by reason, and these have always served as a fruitful field for the operations of imprincipled priests, and been the dupes of the "magician" and the charlatan.

During the nineteenth century the craft of the herbalist fell into disrepute, chicfly because men's minds were carried away by the discoveries concerning the nature and functions of plants and herbs which were being made by the men who were steadily endearouring to establish a scientifie system of pharmacology. Secondary causes were the intense conservatism and ignorance of the herb-doctors and the dealers in herbs, who refused to believe anything about the world of plants used in medicine which was not to be found in the antiquated Herbals of Grattarola of Bergamo (1515-1568), and 'I'urner's New Herball, which was published between 1.551 and 1568, and the Herbal of Gerarde (1545-1607), the herb-gardener of Lord Burghley, and the Physical Directory which Nicholas Culpeper (born 1616, died 165+) published in 1649. This last-named work in no way deserved the excessive abuse which was heaped upon it by interested persons. Here is an example quoted by the IJ.N.B. from the periodical Mercurius Pragmaticus, No. 21, 1649. 'This book is "done (rery filthily) into English by one Nicholas culpeper, who commenced the sercral degrees of Independency, Brownisme, Anabaptisme; aldmitted himself of John Goodwin's schools (of all ungodlinesse) in coleman Strect; after that he turnod siecker, 
Manifestarian, and now he is arrived at the battlement of an Atheist, and by two yeeres drunken labour hath Gallimawfred the apothecaries book into nonsense, mixing every recoipt therein with some scruples, at least, of rebellion or atheisne besides the danger of poysoning men s bodies. And (to supply his drunkenness and leachery with a thirty shilling reward) endearoured to bring into obloquy the famous societies of apothecaries and chyrurgeons."

'There seems to be little doubt that the Physical Direclory and Culpeper's later work, the English Physician Enlarged, were recognized as authoritative by a very large number of people. Of the last-named work five editions appeared before 1698, and further editions appeared as late as $\mathbf{1 8 0 2}$ and 1809 . We may note in eonnection with these facts that Dr. G. A. Gordon prepared a collective edition of culpeper's works which appeared in 1802 .

In these works, and in others of similar character, common sense and even common decency were alike set at nought, and in these days it is very hard to understand how preseriptions like the following could ever have been written and published.

1. For Eprempsy. " Vitriol, calcined until it becomes yellow; saturate with alcohol, add mistletoe, hearts of peonies, elks' hoofs, and the pulverized skull of an executed malefactor (!) : distil all these dry rectify the distillate orel "astoreum (species diamoschi dulcis), clephants" lice: then digest in a water-bath for a whole month, after mixing with salt of peony, alcohol. liquor salis porlarum ot rorallormm, oil of anisi and suroini" (Balas, Misk. Moll., p. 1.36). 
2. 'Tixcture of Mumar.-"Select the cadaver' of a red, minjured, fresh, minspotted malefactor 2+ years old, and killed by hanging, broken (sic) on the whecl, or impaled, mpon which the moon and the sum have shone once: cut it in pieces, sprinkle with myrrh and aloes; then marerate for a few days, pour on spirits." etc. (Ibid., p. $436)$.

3. Extraction of a Tooth. "The powder of earthworms, of mice dung, and of a hare's tooth, put into the hole of a rotten tooth, it will drop) ont without any instrument" (Culpeper"s Last Legacy, p. 10\%).

The men who invented and published such disgusting prescriptions as the above did the craft of the herbalist much harm, but it must also be confessed that in the "sixties" and "seventies" of the last eentury the state of the herbalists' shops, especially those which were situated in the outlying districts of London, was not ealculated to increase the faith of the public in the efficacy of herbs, or belief in the knowledge of those who sold them. Many of my contemporaries will remember a herbalist's shop which was situated in a popular street near King's Cross in the year 1865, and its dirty and unkempt appearance. The shop proper was about 8 feet wide and 20 feet long. Its window front was glazed with small panes of bottle-green glass, which were seldom washed or cleaned, and on the brightest day very little light entered the shop through them; during the winter months, and especially in foggy weather, the shopkeeper was obliged to carry on his business by the light of two or three guttering "dips," i.e. 
tallow randles. A low narrow romuter took up much of the floop spare. On one end of this stool a rickety glass casce containing small bowls of secels and herrics, which were woll roated with dust, and on the other stood a pair of pusty irom srales and a huge glass bowl of a mixture called "sarsaparilla wine." Ien and women, as well as the rhildren, who eame in and spent their halfpennies and pennies freely drank this wine out of teacups of various sizes and shapes and makes, which were rarely rinsed in water, and were usually turned bottom upwards on the counter to dry. A large ardboard label was tied round the bowl, and on this were written in large capitals the names of all the ailments and sicknesses which this particular brand of sarsaparilla wine was said to cure.

On the end wall was a shelf whereon stood a eouple of ostrich ego-shells, and sereral bottles containing "preparations" of rarious kinds, of a most uninviting appearance, and two human skulls. Below the shelf, nailed to the wall, was a small dried crocodile or lizard, and below this a miscellaneous collection of dried "specimens," all richly eoated with dust. 'To the wall behind the counter several narrow shelves were fastened. On one of these stood a row of ycllow glazed pottery jars on which were painted the names of herbs and compounds; some had covers and some had not, and the legends were half concealed hy dust. On another shelf was a series of small bottles and flasks which contained extracts, or decoctions, of herbs, medicated unguents and perfumes and vegetable oils. Another slelf was filled with bottles of medicated sweets, such as paregoric drops. squills, lozenges, sticks of horehound candy, "stick liquorice," 
ete, and these sweets were in great demand by jurenile custonners. Fon the reiling and on the wall in frout of the comnter hung bundles of dried herbs, lavender, rosenary, mint, camomile, dandelion, sorrel and niany others, all well covered with clust. Under the counter were woolen boxes containing poppylicads, sema leaves, malshl-mallow, linseed meal, etc., and a stock of paper bags and phials of various sizes.

'The proprictor sold his wares rather by "rule of thumb" than by measures or seales, and lie eschewed the writing of directions for the use of his patients. He was old and very slabby, but kindly, and many of his customer's were evidently friends and aequaintances, judging by the way in which he adrised them as to their ailments. II sis slop was well patronized by children, who eame there to see him exhibit "Pharaoh's serpents." He would set on a plate a lump of some brown substance rather like chocolate, and when he applied a lighted mateh to a certain part of it, the lump changed its shape and heaved, and from its sides several spirals emerged and went wriggling across the plate like worms, to the great delight of the onlookers. When asked why these wriggling things were called "Pharaoh's serpents," he said that he did not know, but that his father and his grandfather had always called them by this name. When he was unable to advise a customer, he used to knock the eounter with a weight, and then his wife, a little old wizened woman, would appear from behind the shop and take charge of the case. It was generally thought that she was the real herbalist to the establishment, and certainly her reputation in the neighbourhood was great.

The shop described above and its contemporary herbal establishments lave long since passed away, 
and the modern establishments of the Socicty of IIepalists lave nothing to be desired. There are now many signs that the cralt of the herbalist in Grat Britain is regaining its rightful position among the systems of medicine which have been evolved by the gencrations of men in their efforts to heal the sicknesses and discases which attack their bodies and which, if not anmulled, destroy life itself. For the seneral public have learned that the methods now used in extracting the essential juices, ete., from medicinal hepbs, and in the preparation of extracts, tinctures, etc.. are scientific and ac'urate. Moreorer the effects of herbal deugs on the body are better known and understood, and it is now possible to obtain herbal preparations of uniform strength and quality. 


\section{II}

\section{THE DIVINE HERHAIISTS}

IT has already been said that many ancient nations thought that the gods themselves were the first herbalists, and that it was they who had taught their vicars upon earth how to heal the sicknesses of mankind by means of certain herbs and plants. More than this, they thought that the herbs and plants which the gods employed in their work of healing were composed of or eontained parts of the bodies of the gods. And as the operation or effect of a medicine became more assured, or more potent, if a formula was recited at the time when it was administered to the patient, the god or goddess supplied, aceording to the general belief, the words which constituted the formula which was reeited by the herbalist. Thus the medicine itself, and the knowledge of how to administer it, and its healing effect, came directly from the gods. It is then clear that the gods were the earliest herbalists and physicians.

It is impossible to say exactly which nation possessed the oldest gods of medicine. Of the Chinese grods of medicine little seems to be known. Some authorities claim that an Emperor of China called Inang-ti, who reigned about B.c. 2637, composed a treatise on medicine, and that another emperor, Chin-nong (B.C. 2699), composed a catalogue of Chinese herbs, or a sort of pharmacopœia, but satis- 
liactory cridence in support of these statements is wanting.

We have it on the high authority of 1)r. Isonel Barnett that the carly history of Indian medicine is very obscolle. 'That very ancient work the Atharavêda contains a rast quantity of spells to heal sickness, cxorcise demons, and overpower sorecers, love-charms (as a rule by no means innocent), and incantations of various kinds. None of the works in use in the medical schools of India is older than the beginning of the Christian cra, and we annot, therefore, consider the gods of India as the oldest herbalists or physicians.

Many Greek witers describe the remarkable skill of the layptian physicians, and refer to the great antiquity of the study of medicine in Egypt, and it was thought for a very long time that the dwellers on the Nile were the inventors of the art of healing. Manctho tells us (Cory's Fragments, p. 112) that Athothis, the son of Menes, the seeond king of the Ist Dynasty, was a physician, and that he left behind him books on anatomy. Now the latest date we can give to this king is about B.C. 3600, but Närmer-Men, whon the Grecks knew as Ménes, was a foreigner, and there is reason to believe that he came from some country to the east of Egypt. 'Therefore the books on anatomy which his son, or grandson, left behind him, were probably works by men who were not Egyptians.

The tombs and the buildings of the sucecssors of Athothis prove that in their time the arts and crafts had attained a high pitch of perfection, and certain chapters of the Book of the Dead were cither romposed or introdnced into the oflicial religion at this period. It is dillicult to beliere that the indigenous 
Egyptian did all the things that he is elainned to have done. and more dillicult still to think that he built the famous "Step l'yramid" (still 19 r feet in height). except at the suggestion of and with the help of forcigners. Imbetep, the Warâr of King 'Teneser, whose tomb the step lyramicl was intended to be, was a ereat arehitect and a great physician, and was worshipped as a god alter his death. The Grecks identified him with their great god of medicine, Escrulapius, and Manetho says that he "built a house of hewn stones, and greatly patronized writing." We may note in passing that this house of hewn stones has been recently discovered by Mr. C. Firth of the Egyptian Service of Antiquities, and excavated.

Now it must not be assumed that the indigenous Egyptians had no knowledge of the use of herbs in medicine in the fourth millennium B.C.; on the contrary, there is reason to believe that they were well aequainted with most of the herbs and plants which we find mentioned in the great Ebers Papyrus. But it is very probable that the medieal knowledge of their Asiatic conquerors was greater than their own, and that Imhetep was the first to reduee to writing or to edit for them an authoritative book of medicine. It is a well-known fact that no satisfactory translation of the Ebers Papyrus has been made, or can be made, for the simple reason that we do not know how to translate the names of seores of herbs and plants which are fornd in the prescriptions. It is possible that these are the ancient native names of herbs and plants which were well known throughout the Nile Valley, but not to the later dynastic Egyptians. 
The principal beyptian gods and goddesses who were specially skilled in medicine and the alt of healing wore these: Osiris was a god of regetation in onc of his earliest phases, and at all periods he was associated with the moon. IIe was skilled in the knowledge of plants and was a great agricultural authority and he introduced wheat and one kind of barley into Egypt; he taught men the ('ultivation of the vine and was the first god to make wine. Is the god and judge of the dead he dwelt in a portion of the 'Tuat or Underworld, and the souls of the beatified dead spent their time there in the cultivation of the wonderful Marl plant. 'This plant or shrub was a form of the body of Osiris, and his followers ate it and lived upon it. It maintained their lives, and because they ate the body of their god, they became one with him and, like him, lived for ever.

Closely associated with Osiris was the goddess Isis, his twin sister and wife. Her knowledge of herbs was great, and, as one of the most ancicnt Mothergoddesses of Egypt, she was the great protectress of her husband Osiris, her son Horus, and women and children in general. In the Ebers Papyrus (Plate I) she is addressed thus: "May Isis heal me as she healed Irorus of all the wounds which his brother Set, who slew his father Osiris, had inflicted upon him. () Isis, thou great magician, heal ne, and deliver thou me from all bad, evil and 'Typhonic things, and from crery kind of fatal sickness, and l'rom diseases caused by devils, and from impurity of every kind, eren as thou didst deliver thy son Ilorus from such." In the same Papyrus (Plate XI.VII) we have a preseription for pains in the head which she wrote for the god Rà. As a woman Isis suffered from some 
ailment in her breast, and a copy of the prescription for the medicine which she prepared and used herself is given on Plate XCV.

But Isis was a great magician as well as a great herbalist, and by means of the serics of invincible spells which she was taught by 'Tuotir, and by the use of the secret name of the Sun-god RA, she could vanquish every sorcerer, loose every spell, destroy the eflect of all incantations and poisons, and raise the dead. 'Thus when Osiris was slain by his brother SET, and Isis found his dead body lying on the dyke at Netat near Abyclos in Upper Egypt, she brought it into the city and restored life to it for a scason by means of the magical touch of her sex and the powerful spells which she uttered. Osiris rose up from his state of inertness, and eonsorted with Isis, and their son Honus was born as a result of this embraee. One day, whilst living in the papyrus swamps of the Delta, she was obliged to leave her son Horus for a short time, and during her absence Set sent a scorpion, which crawled to the place where the ehild was sleeping and stung him to death. When Isis returned and found his dead body, she appealed to Rā, who stopped the Boat of Millions of Years in which he was sailing over the sky, and sent down Thoth to help her. Thoth imparted to her certain words of power, and when these were uttered by the goddess Horus was restored to life.

On one occasion Isis used her knowledge of poisonous herbs for a selfish purpose. She wished to possess as much power as Rāa, and to learn the secret name by virtue of which he ruled the heaven and the earth. and gods and men. As Rä did not wish to reveal his secret name to her, she made a reptile, and 
having recited enchantments over it, she set it by the side of the roat over which Ra travelled daily. As lia passed the reptile it bit or stung him, and the poison which it injected into the god was so deadly, and so swilt in its working, that the strength of the god ebbed rapidly and he was nigh unto death. Isis approached the god as he was in his death agony, and promised him that if he would reveal his secret name to her she would heal him. In his extremity Rà did so, and as the result of the incantations which Isis pronounced forthwith the god recovered.

The god 'Tluotri, to whom Isis appealed in her distress, was himself a very great and powerful physician and magician, and was the author of all the formulas which enabled human physicians to heal sicknesses and to drive out devils and evil spirits from the bodies of their patients. His name was so powerful that if a man called himself 'Thoth, he at once acquired the attributes of the god. Thoth had on certain oceasions practised as a physician, for he treated the Eye of Horus, i.c. the Sun, when it was wounded by set, and restored it to its normal eondition. During the fight between Horus and Set, Thoth seems to have had his arm either broken or seriously injured, and he was obliged to employ his knowledge of medicine and magic to heal himself. On another occasion he was associated with Rã in composing a prescription for catarrh in the nose. or perhaps a kind of influenza (Libers Papyrus, Plate X('). From the earliest times 'Thoth was regarded as the anthor and copyist of the powerful spells which he used, and he possessed in a very lull degree that marvellous quality or power alled Heks, which Rã himself had invented for the benefit of geods and 


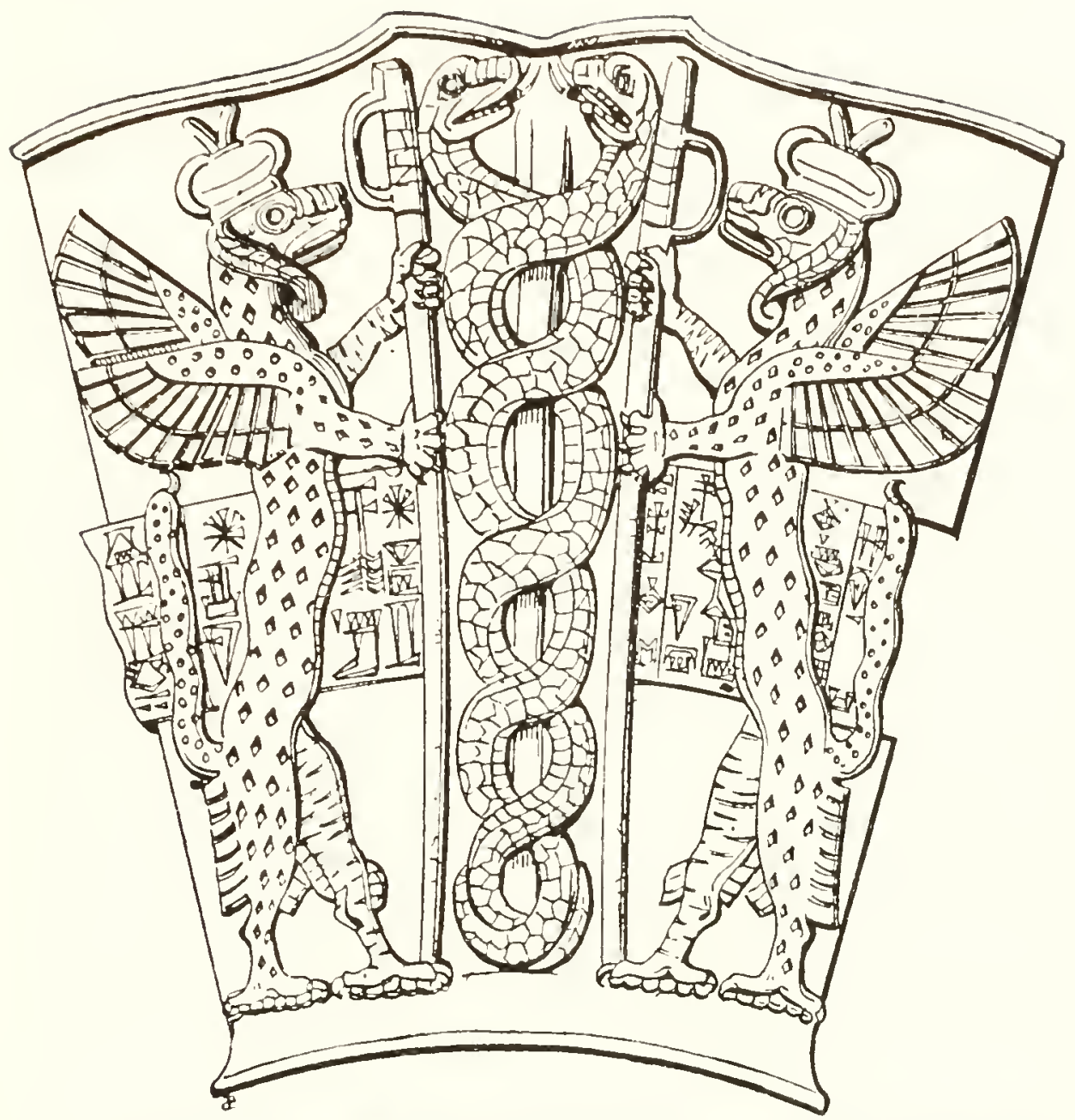

In the ecntre is a stafl with two serpents twincel about it, the cmblen of the sumerian god Ningishzida, the son of Ninazu, the Masterplysicoian. On cach side is a fabulous composite corature wearing a headdress with horns, and having the head, wings and clatw's of all cagle and a serpent tail; cach holds a staff. 'I'he names and attributes and functions of these mythological creatures are not known.

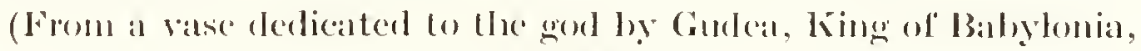
13.(. . 23:30.) 

men. He was at once the heart or tongue of Rā, and the secretary of Rā, and as the Keeper of the Book of the god he bore the title of Kusk mes. In late dynastic times he was called "Thoth the thriec areat," or "Thoth the thrice greatest," and in basrelief's the 'Thoth of Nubia is represented as holding' the ankh or symbol of life in his left hand, and in his right a stafi round which a serpent is coiled. We may note in connection with this serpent-encircled staff, that the symbol of the Sumerian god Ningishrida, the son of Nina\%, was a stall around which two serpents were coiled. 'The serpent was chosen as a symbol of renewed life or immortality because it sloughed its skin, and so apparently renewed its life and health. As already stated, the serpent-encircled stafl is the symbol of physicians to this day.

Another most important god of medicine was Axpe, whom the Greeks called "Anubis." He may be regarded as the Apothecary of the gods of Egypt, for he was the keeper of the house of medicimes and the "chamber of embalmment." 'The dead body of Osiris was taken to him, and whilst Isis recited her spells and incantations, Anubis carried out the operations comnected with the embalmment of the body of the god and the preservation of his viscera. 'The cult of the god in Egypt is very ancient, and the introduction to a prescription in the Ebers Papyrus (Plate CIII) says that the prescription itsell was taken from a book whirh was found under the feet of the god Anubis in the town of Isetopolis, and that the book was taken to senti, the fifth king of the Ist Dynasty. In the medical papyrus at Berlin this book is said to have been taken after the death of King Semti, to Sent, a king of the IInd Dynasty. 
'Thus it is clear that the byetians possessed books of medicine in the first hall of the fourth millennium before Christ, and that Anubis was cren at that carly period regarded as the Apothecary and the maker-up) of prescriptions for the gods. Anmbis was the keeper of mummies in the (Other World, and we see him taking part in the weighing of the heart of the dead in the Hall of Osiris, and examining the tongue of the Great Scales on behalf of 'Thoth and Osiris. The animal sacred to him was a dog or jackal, and together with Upuatu he conducted the souls of the dead from this world to the kingdom of Osiris. We may note in passing that the Sumerian goddess Gula, "who made the dead to live," the wife of Ninurta, is represented seated on a throne with a dog at her feet. In one of their magieal systems the Gnostics connected Christ, as the Saviour and knower of hearts, with Anubis, the embalmer and preserver of the hearts of men.

In the legend of the "Destruction of Mankind" by the goddess HaThon we read that Rā caused 7000 vessels of drugged bees to be made. The drug used for the purpose was tataiti, which grew in abundanee at Elephantine, at the foot of the First Cataract; Brugsch and others have translated the word by " mandrakes," but this rendering is not wencrally aceepted.

Another great god of medicine was Kuoxst. Who with Antex and Mere formed the first triad of 'Thebes. One form or phase of him alled Knonse NererHETEP deroted himsell to the cule of those who sulfered from mental ailments. It is recorded that the Prince of Bekliten sent an cnvoy to Rameses II (?). King of keypt. Who had married one of the Prince's 
daughters, asking him to send a physician to l3ckhten to heal his youmgest daughter, who was gricrously sick. Rameses sent a physician to Bekhten, but he was mable to heal the Princess, and the Prince, her father, sent a second time to Rameses, and asked that a god might be sent to heal his daughter. With the cousent of Khonsu, the god Khomsu Nefer-hetep was sent, and he found on arrival that the Princess was possessed of a devil. 'The god easily cast out the devil from the Princess, and restored her to health forthwith. 'The Prince of Bekhten made a great feast, at which both the god and the deril assisted, and the deril was permitted to depart to his own place. Unfortunately the Egyptian text does not tell us whether spells or medicines were employed by the god in casting out the devil from the Princess. 


\section{III}

\section{WATER A DIVINE ELEIENT}

MAx cannot live by bread alone, although wheat was believed to have been formed of the body of God, and without water he could not live at all. II whole existence depends upon it, and from the earliest times man has regarded water as a thing of mystery and has attributed to it supernatural and animistic powers. It wave life to himself and the beasts and the vegetable creation, and it was to him a thing of indefinable and inscrutable origin, and possessed of a divine essence. According to the Egyptians the oldest thing in the world was the great watery abyss called "NU" or "Next," and from this sprang the first god, RA, or KuEperA, who created the heavens and the earth from the germs which existed in the abyss. Fron out of this abyss the primeral god sent a river into Egypt. which was thought to enter the country from two openings in the bases of the rocks at the First Cataract, and this river we know as the Nile. The throne of (Osiris was set over or by this river, and when the digyptians became Christians they placed the throne of God by the great river of heaven. whence ame the Nile, and IIe regulated the supply of water to bigpt with IIis lect. 'T'o the Egyptians water was the "Father of the gods," and the Nile was the "water of life," which not only preserved life in the living but revivified 
the dead. In labylonia the great rivers the 'Tigris and Euphrates had their origin in the great primcral abrss Apse which was the abode of the god Ex. Is in Egypt, so it was in Babylonia, water was holy and divine, and was, of course, worshipped as a got. Both in Egypt and Babylonia it was used largely in medical, magieal and religious ceremonies of all kinds, for it was regarded as the supreme cleanser of both soul and body. Pagan philosophers believed that water was in existenee before God created the heavens and the earth, and the Egyptian Christians said, "there is no one whatsoever who knoweth anything about the ereation of water exeept God IIimself.' They also plaeed water, the wheat plant and the throne of the Father in one eategory, and regarded them as the equivalents of the Son of God. In seores of preseriptions given in the Ebers Papyrus water forms one of the principal ingredients of the medicines. As to the wheat plant. From the Egyptian texts we know that in one of his many aspects, or phases, Osiris was a grain-god, and Greck writers say that he introduced wheat and the vine into Egypt and many other countries. Egyptian texts and pictures indicate that wheat plants were believed to spring from his body, and the grains of wheat were parts of it. 'The Egyptian Christians adopted this view, only they substituted the body of God for the body of Osiris, as we see from the following legend: Adam and Fre being expelled from Paradise, where they had lived upon choice food, were unable to eat the coarser foods which they found outside Paradise, and in consequence they suflered greatly from hunger and want, and were nigh to dic of starvation. One Lord, Who was Adam's sponsor, went to the lather 
and asked IImo il IIe wished Ackam, whom IIe had crated in Ilis own image, to dic of starvation. In answer the Father tolel our Lorel that IIe had hetter wive IIs own flesh to Adam to eat, and IIe did so. (111 Irorel took flesh from ITis right side and mbbed it down into gans. and took it to the rather, Who. on secing that our Ioord had obered IIis command. took some of IIs own flesh, which was invisible, and formed it into a grain of wheat, and placed it with the flesh of His Son. He then sealed the grain of wheat in the middle with the "seal of lioht," and told om Iord to take the grain and give it to Michael the Archangel, who was to take it to Adam on earth and teach him how to sow and reap it, and how to make bread. When Michael came to Adam he found him by the Jordan and learned from him that he had had nothing to cat for cight days. This legend is found in a Coptic manuscript in the British Museum (Orient. No. 7026). The Coptic text is published with an English translation by Budge, Coptic Ipocrypha. London, 1913, p. 59 f. and p. 241 . In an Assyrian text published by R. C. 'Thompson we find Shamash, the Sun-god, and Sin, the Moon-god, associated with the growing of wheat. 'Thus we read: "Thou didst make the standing crop to spring up : reaping. binding; binding. car; car. [threshing?. Shamash when he reaped. Sin when he garnered . ." (Proc. Royal Soriety of Medicine, 1924, Vol. XVII. pp. 1-34). The prescriptions in the Ehers lapyrus show that flome, dough, and bread, fresh or stale or toasted, were all used in medicine as vahable ingredients.

Rotmrning for a moment to the belief in the holiness of water, we may lecere to the water of the ancient and fannous sum-well at Ileliopolis. 'The pagan 
legetians attached ereat importance to bathing in the water of this well, and belicved that purity of somb and health of body were obtained by the bather thereby. 'The reason for this belicl was the ancient Fyptian tratition that when Ră, the Sum-god, rose on the workl for the first time he bathed his lace in the water of that well. Acoording to Christian traclition, Mary washed on Lord in wated drawn from this well, and when the water was thrown out on the ground, wherever any drops of it fell, balsam trees sprang mp. From these shrubs a "holy oil" ralled "Mīron" was expressed, which was used for anointing at baptisms and consecrations and other important sacred rites and ceremonies. For centuries it was used as the oil of consecration par crecllence, and when, as it sometimes happened, a supply of it was not fortheoming, eonsecrations of ecclesiastical officials had to be postponed. 


\section{IV}

\section{VEGLTMBLE SUBSTANCES OF DIVINE ORIGIN}

Accordoxa to a magial papyrus in the British Museum (No. 10051, Salt 8.5), the connection between the gods and rertain regetable substances was rery close. The tears that fall from the eyes of IIorus turn into the gum anti. i.e. myrrh. The blood that falls from the nose of GEBBix turns into cedar trees, the sap of which is the oil "Sefi." On certain oceasions SHe and 'TeFret weep, and when their tears reach the ground they sink into the earth and transform themselves into the plants from which incense is made. When RT weeps copiously the water on falling on the ground becomes "the flies that build." i.e. bees, and these, working in the flowers in every garden, produce honey and wax. The Water Flood (i.e. the annual Inundation of the Nile) on earth is composed of the sweat which falls from Ra when he is weary, and the other exudations from him turn into papyrus plants. 'The sweat of the goddesses Isis and Neplaturs turns into plants. 12.1 in the house of the Sun-stone sweats. P'TAll in 'Tanen sweats, Kuxbue in the Qerti of Elephantine sweats, Osins in 'Tetu sweats, and Silu and 'TEFxut rollert these sweats and fashion them into plants that are the members of the god. The blood of Osimis became the Nart tree of Amentt, and the blood of SEe became the Nairt tree of Abydos. All the plants and the 
oils of the trees mentioned above were believed to be powerful medicines, and played very important parts in all the rites and aremomies connected with the resurrection of the dead. In the Graco-Roman period (hilden and others were huried in pots filled with honey, and the body of Alexander the Great is said to have been preserved in "white honey which had not been melted." 


\section{V

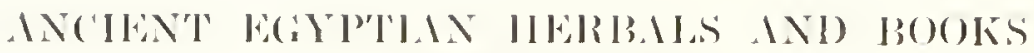 OH IIEDIC'INE}

'Tnougen there is good reason for believing that official S'chools of IIcrbalists existed in Eeypt as early as B.(4. :3000), not one of the theoretical works on which the physicians of that day based their practice has come down to us. All the ropies of medieal papyri now known' were written after B.(. 1800, and their contents are series of prescriptions which were probably in enenal use among the various schools of herbalists in the country. The actnal prescription is preceded by a description of the symptoms of the disease which the medicine is intended to cure. and is followed by instructions for the preparation of the ingredients, and for the taking of the medicine by the patient. In some cases a magical formula, which is to be recited sometimes by the physician and sometimes by the patient. is added. It is possible that the libraries in the temples, or those of private individual physicians, contained books dealing with

1 These are:- (1) the ereat bibers Papyrus (published in fiac-

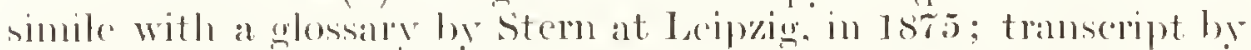
Wrestinski, ladprig. 191:3). (2) The great medical paprus it Bertin (No. 30:32, published he Brugserh and Wreszinslii). (3) The medical papyrus in the IBritish Mhesem (No. 100.59). (1) The Inalst I'aprous (published Wr Wrestuski in 1912). (5) The

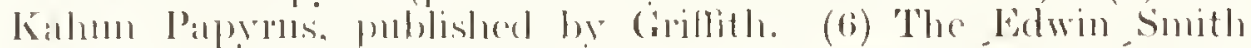

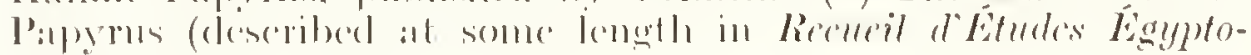

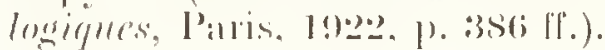


the theory of medicine, and complete lists of plants or Herbals. but nothing of the kind is known to exist at the present time. 'The prescriptions show that the Eygptians used animals and animal products, and mincral substances, as well as plants in their medicines, but there is no donbt that live-sixths of the ingedients were of regetable origin. We find as ingredients in prescriptions the dung of asses, dogs, pigs, gazelle, crocodile, etc., and many other cril-smelling and evil-tasting stuffs such as rotten fish and the gall of various animals; but this need not surprise us, for we find the very same smbstances are prescribed in Babylonian, Creck, Syrian and European IIerbals.

The men who cut open and prepared the bodies of the dead for mommification by removing the viscera and brains, must have known something of elementary surgery, but it seems clear from the material now available that neither they nor the physicians possessed any real knowledge of Anatomy and Physiology. Yet the Egyptians were renowned in ancient days for their knowledge of plants and herbs, and Hippocrates and others incorporated in their writings many prescriptions which they had taken from the medical papyri of the Egyptians. There may have been, and there probably were, many physicians and herbalists who studied plants and anatomy in a scientific manner, and who tried to understand the working of the organs of the body, and the actual effect of the herbal medicines which they prescribed for their patients. Such men, if they existed, no doubt made experiments and noted the results which they obtained; and it is probable that some physicians endeavoured to discover Nature's operations by means of dissection and even by vivisection. But the majority 
of practitioners relied upon the use of spells and magical ceremonies, and made their treatment to suit the views of their patients, who as a whole believed in magic. 'The progress of herbal science was strangled by the belief in magic which was general among the people. Men thought that every illness was caused by the operation of one devil, or more than one, who had oeempied the limb or nember of the body. and had destroyed the protecting influence of the god or good spirit that usually dwelt in it. The first thing to do was to expel the devil, and this could only be cffected by a spell or the utterance of the name of some great god; when the devil had been expelled the herbal treatment of the body began. kvery nember of the body of a living man was protected by a god, and the Book of the Dead (Chap. XLII) shows us that the nembers of a dead man were believed to be protected in the same way. Thus Pepi I, a king of the VIth'Dynasty, says : "My hair is Nu. My face is Aten. My eyes are IIathor. My head is Horus. My nose is Thoth. My mouth is Khens-mr. My backbone is sma. My breast is Babu. My heart is Bastit. My belly is Nut. My phallus is Iapi. My thighs are Nit and Serqit." etc. And in the Papyrus of $\mathrm{Nu}$ in the British Museum (No. 1047\%. sheet 6) the deceased says: "There is no menber of my body which is not the menber of some god. The god Thoth shieldeth ny whole body and I an laa (the Sun-god) day by day." 


\section{VI}

\section{HOLY OILS IND MEDICATED UNGUENTS}

Tne Sumerian, Akkadian and Egyptian herbalists learned at a very early period in their history the value of vegetable oils for the soothing and the healing of the body and the feeding of its tissues. They found that oil protected the skin from the heat of the sun by day, and that it enabled them to endure more easily the bitter cold by night in the deserts of Egypt and the Südān and in the bleak plains of Mesopotamia. In Egypt the regetable oils were thought to be effluxes from the body of Rā, the Sun-god, which had taken the form of eertain trees, e.g. the olive, the acacia, the palm, ete. Whether the Egyptians thought that the gods and goddesses needed oils for their personal use is not clear, but it is quite certain that in all periods offerings of pure oil and perfumed oil or scented unguent (Metchet) were made by worshippers, and were accepted by the gods. Wine was offered at the same time as the oil, and from the antiquity of the custom, which was widespread, we may assume that the gods were supposed to gladden their hearts with the wine and refresh their bodies by anointing them with the oil. The primitive herbalist used oil both to keep the body in health and to nourish it, and, as we see 
from namy prescoptions in the Eshors Papyrus, used it frecly in his medicines.

Tery soon, however, the anointing of the body ande to have a ritual significance, and crentually Linction "ance to play a very important part in sacramental religion. The dead were anointed as well as the living. and the presence of the oil on their bodies was believed to assist their resurrection. Like water, oil was regarded as a thing of mystery, and a holy character was assigned to it. 'The Hory Ors were seven in number' and were called Seth-heb, IIeknu, Sefth, Nemu, 'Tuaut. Ia-āsh, IIa-ent-'Thchennu. Examples of the anointing tablets on which the names of these oils are inscribed can be seen in the British Muscum (Nos.6122, 612:3, 29421). 'They were used in the tombs of Heypt under the Old Kingdom (about B.C. 2500). At the presentation of each oil the Kíner-Hes or priest recited a magieal formula or spell, and sometimes he made motions with his professional rod or staff with the view of increasing the effect of the oil on the body. In the Ebers Papyrus several kinds of oil are mentioned, e.g. "white oil," "clear oil," " Her oil," "tree oil," "olive oil" (Baq). A special oil was used in circum(ision ('Tsheps), and 'Tchet oil was an ingredient in the famous incense called "Kyphi." The primitive herbalist was the first to discover the value of oil as a medicine, and it was by arting mpon his knowledge that the priest was able to turn the secular act into a religions repemony. The anointed one became holy becanse a holy substance had been incorporated in him; anome the IIebrews anointing was believed to endow the man ahosen by them to be their king with the l)ivine Hissence. And Jesus the "Messiah" 
(i.e. "Meshīkhā," the "anointed (One," i.e. ('hristos) was endowed with the Iloly Ghost.

Another thing realized quickly by the primitive herbalist was that oil was a first-class vehicle in which to administer medicines to the sick; in some of the prescriptions in the Ebers Papyrus we are told to boil all the ingredients together in honey and oil, or in oil alone. He also discovered that men and women were glad to anoint their bodies with perfumed oils, and thus originated the trade in ointments, salves, pomades and scented unguents which has assumed such great proportions in our own days. The Ebers Papyrus contains more than a dozen preseriptions for salves and ointments, and the preparation of scented as well as medicated oils and unguents was from the earliest times a very important branch of the herbalist's business.

The perfuming and anointing of the body beeame at a very carly period a part of the RITUAL OF CEREAIONIAL Dress, both of the living and the dead. Jezebel the wife of Ahab (as we read in 2 Kings ix. 30) "set her eyes in paint" and decorated her head before the arrival of Jehu. And one of the mummies found at Dēr al-Bahari shows that the custom of anointing the eyclids of dead princesses, and colouring their lips red, and staining the nails of the fingers and toes reddish-yellow with the juice of the heme plant (Laweronia inermis) was prevalent in Egypt. Whether the "lip-stick" was known to the Egyptians is not clear. In a painting on a papyrus at 'Turin a lady is seen holding a mirror in one hand and colouring her lips with what looks like a reed or pencit which she holds in the other; but this object may 
well have been the ancient equivalent of the "lipstick."

One farourite way of applying menent to the body in use among the Egyptians is made known to us by pictures in the tombs. Men and women alike fastened on the top of the head a sort of conical cage made of some light material like grass, and in this they placed a large lump of scented unguent which tonched the hair. The heat of the head melted the unguent, which gradually ran down over the head and saturated the hair and dripped down on to the neck and shoulders. 'The relatives of the dead placed in the tombs supplies of this unguent, together with metal or alabaster shells on which to prepare it for use. Small bottles and flasks, made of alabaster or glass, filled with scented oils and ointments, were also placed in the tombs, and many hundreds of these may be seen in the British Museum. 'The Egyptian herbalist paid great attention to the care of the skin, and even provided the dead with pieces of pumice-stone with which to rub down callosities (see the funcrary cofler of the lady Anhai in the British Musemm).

The herbalist also provided means for preventing baldness. (One means was to mix together fat of the lion, fat of the hippopotamus. fat of the crocodile, fat of the cat, fat of the serpent, and fat of the Nubian ibex, and rub the mixture on the head.

The following hair-wash was used for (2ueen shesh, the mother of King 'leta :-

$\left.\begin{array}{l}\text { 'The claw of a dog, } \\ \text { Decayed palm leaves, } \\ \text { The hoof of an ass, }\end{array}\right\} \begin{gathered}\text { in equal } \\ \text { quatities. }\end{gathered}$ 
Boil thoroughly in oil in a pipkin and rub the mixture on the head.

'l'o kecep the hair from falling out :-

1. Mix together artists colour, collyrium, Khet plants, oil, gazelle dung and hippopotamus fat, and rub the mixture on the head.

2. Mix crushed flax seed with an equal quantity of oil, add water from a well, and rub the mixture on the head.

3. Boil a lizard in oil and rub the oil on the head. (Ebers Papyrus, Plates LXVI, LXVII.)

As specimens of other prescriptions of the Egyptian herbalist may be quoted :-

1. Aganst costrveness. Honey, seeds of raisins, absinth, elder-berries, berries of the uan tree, kernels of the utchäit fruit, caraway seeds, äam seed, thäm seed and sea-salt in equal quantities; make up into a bolus and administer through the anus. (Ebers Papyrus. Plate IX.)

2. TO STOP DARRIIGa. Spring onions $\frac{1}{8}$, Groats recently boiled $\frac{1}{8}$. Oil and IIoney $\frac{1}{4}$, Wax $\frac{1}{16}$, and $\frac{1}{3}$ of a tena of water; boil together and drink for four days. (Lhors Papylus, Plate XIV.)

3. To EMP'T THE BeLLY and rear out all impurities from the body of a sick person. Field

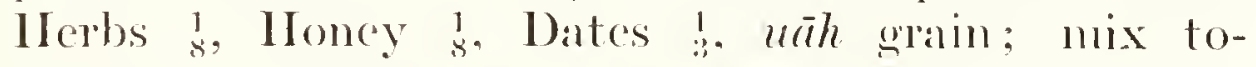
gether and rlace for one day. (Libers Papyrus, Plate V'II.) 
The following is a transcript of the hicratic text in hicroglyphs:

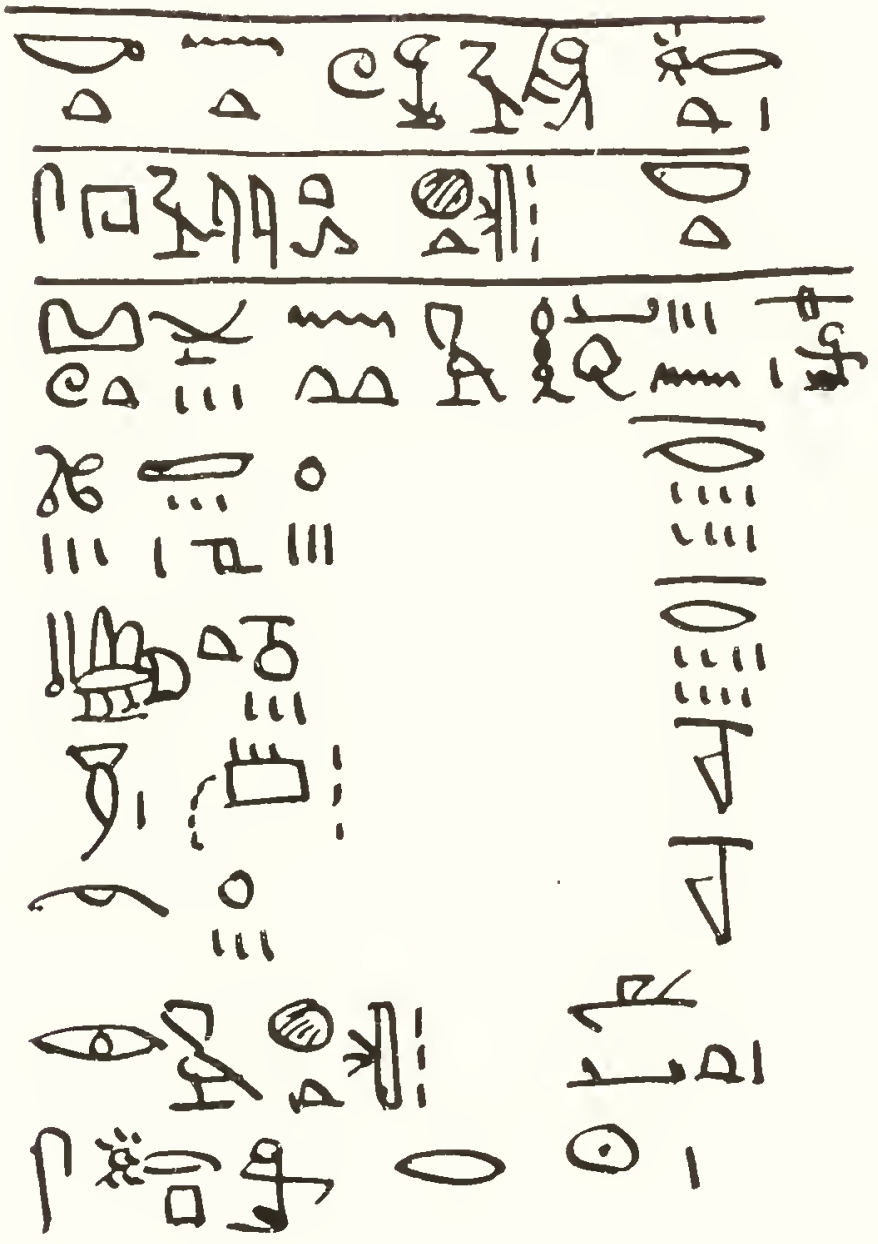

4. 'Jo STOP SUFFUSION OF BIOOD IN THE EYES. 'lake two shells of clay. Fill one of them with the poweler of the fruit of the dum pah [mixed with] the milk of a woman who hath given birth to a boy. and fill the other with aow"s milk and kecp it from curdling. In the moming fill both thine yes with the mixture of düm palm powder and woman's milk. and alter that wash both eyes in the cow's milk lour times a day for six day's. (Ehores l'apyous. Plate I.X.) 
HOLY OILS AND MEDICATED UNGUENTS 35

The following is a transcript of the hieratic text in hieroglyphs:

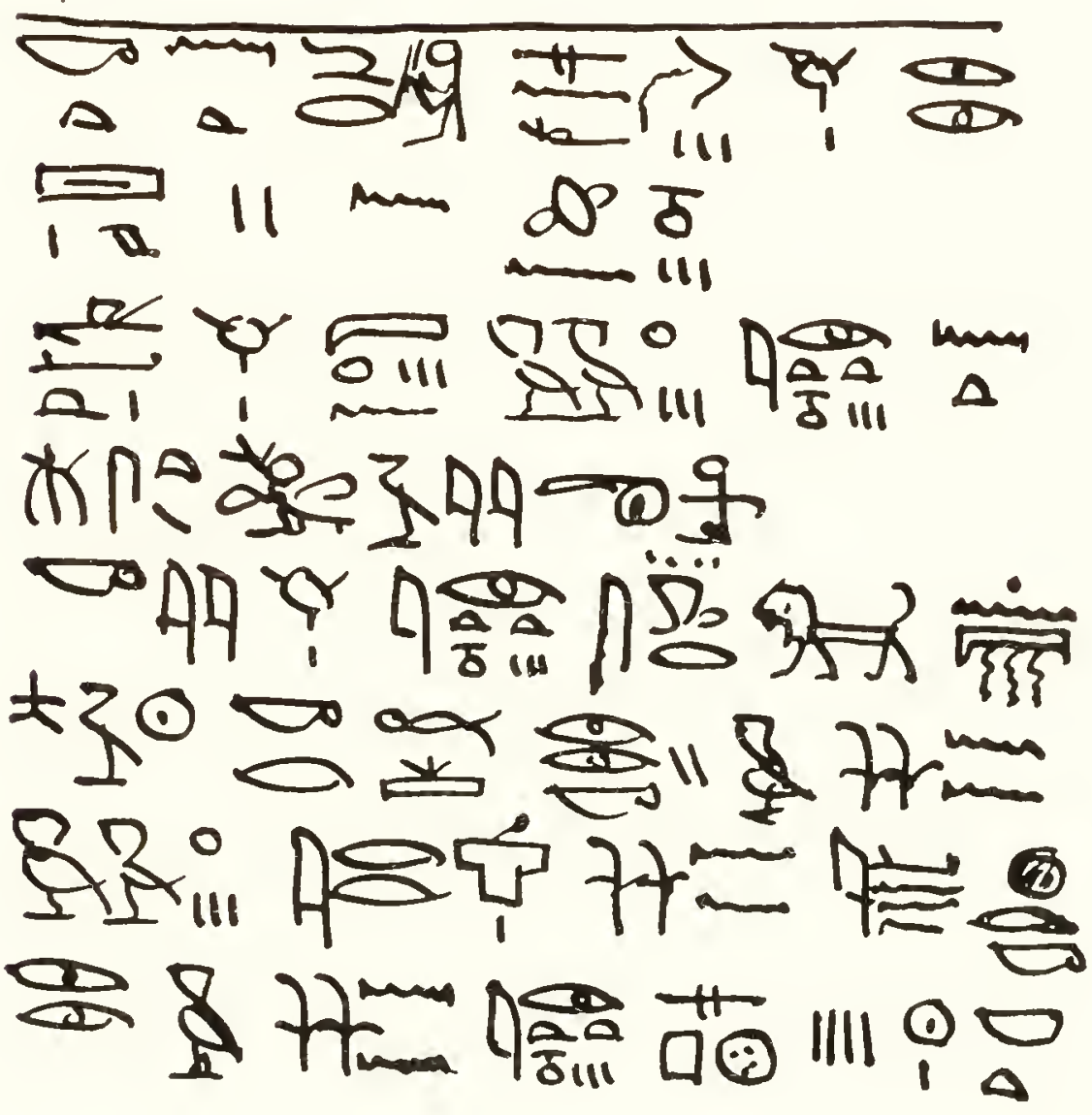




\section{VII}

\section{SUMERILN AND ISSYRIAN HERBALS}

'THe Sumerians and the later dwellers in Mesopotamia believed that erery sickness and disease which attacked the human body was caused by the operations of devils and evil spirits. 'These, it was thought, could only be expelled by the utteranee of spells or incantations and charms, and when these failed reeourse was had to what we should call "medical treatment." Probably the oldest treatment consisted in washing the patient with water, which was a divine element, and was derived from the great storehouse or abyss of waters called by the Sumerians "Apsū." This was the home and dominion of the god $\mathrm{E}_{\mathrm{A}}$, who was regarded by herbalists and physicians as their patron, and the founder of the art of healing. At a later period many other gods were believed to be physicians, e.g. the goddess Ninkmursag, and her company of eight gods, each of whom presided over one of the branches of medicine, and Ninazn, the "lord of physicians," or the Masterphysician. 'The god Nexerta was eredited with the power to destroy and render ineffective the spetls of sorereres and others, and his wife Guta used her great power in revivifying the dead.

When the Sumcrians began to compile their Iterbal ramnot be said, but a lablet which was at one time in 
the Library of Ashurbanipal, King of Assyria, 13.C. 668-626, at Ninereh, and is now in the British Museum (K 40.23), has a note at the end of it which says that it was copied from a tablet which had been written in the second year of the reign of Enlil-bani, King of Isin, about 13.C. 2201-217\%. And the note refers to a tradition from the time of "the ancient rulers before the Flood which was in Shurippak." 'Thus it is elear that the Sumerian IIerbal was in existence in the second half of the third millennium B.C. Copies of medical tablets have been found at "the city of Ashur" which are sereral centuries older than those of Nineveh, and the medical tablets discovered at Bogaz Koil prove that the Hittites possessed copies of texts which were probably made from Sumerian or Akkadian (Babylonian) archetypes. Whether the Sumerians were the discoverers of the arts of healing which they employed eannot be said. Their arts have much in common with those employed by the Egyptians, if we may judge by the eontents of the Ebers Papyrus, and it seems as if the art of medicine had already become nationalized in the third millennium B.C. At all events it cannot be said with certainty that the Egyptians borrowed from the Sumerians, or that the Sumerians borrowed from the Egyptians; the probability is that both nations borrowed from a common source, and the present writer thinks that that source was far more likely to have been Asiatic than African. Of the folkmedicine of the aboriginal inhabitants of Mesopotamia, and that of the aboriginal inhabitants of Egypt, nothing whatever is known, but it is quite certain that few, if any, of the Egyptian and Sumerian herbalists and physicians ever succeeded in freeing 
themselves from the trammels of influence of magic and solecery.

'The knowledere which we possess of the Issyrian IIcrbal is derived from the baked ralay tablets and fragnents which have been fonmd among the puins of the great library of the temples at Ninevel and the Royal Library of Ashmbanipal, King of Assyria, 13.C. 608-626, at Nincveh. 'This king was a incat patron of leaming and he spared no pains in filling his Library with series of well-made, well-baked, and alefully written clay tablets dealing with grammar. history, religious and profane literature, magie. omens, incantations, divination, astrology, cte. Many of his tablets were written in two languages, Sumcrian and Assyrian, and the information derived from them is practically the foundation of the modern science of Assyriology. Had these tablets come down to us in a complete state we should have been able to translate the medical texts and reconstruct the Assvrian Herbal without difficulty, but, alas, the number of complete tablets which late has saved from the I ibraries of Ninereh are comparatively few, whilst the lragments of tablets number about 40,000! 'These all have been brought from Ninerch by the late sir IIemy Layard and the other excavators, who have been sent ont by the 'Trustees. and they are now preserved in the British Musenm. The andition of these framents tells the story of the ill-treatment which they received on those awhl days in the year (i12 13.c. when Ninevel was captured by her enemics. and her palaces and temples were pillaged and burnt. and her precions literary treasures were smashed in pices and their fragments scattered in all directions.

'The scribes of' Ashmbanipal compiled bilingual lists 
of stars, comntries, ditics and towns, stoncs, animals, woods, trees, cte. and their lists of plants formed the rarious sections of the Assyrian Herbal, that is to say. the Ilerbal which was compriled in Assyria, probably in the seventh century 33.c. 'The first to publish any portions of these lists was sir IIenry Rawlinson (see C'unciform Inscriplioms of I'estern Asia, Vol. I1, London, 1866). Many scholars, English, French and German, began to give their attention to the medical texts generally, and to publish small groups of texts together with such translations as the knowledge available at the time permitted. Many scholars, e.g. Küchler, Scheil, Jastrow, Langdon, Virolleaud, Boissicr and Ebeling, have made valuable contributions to the science of Mesopotamian medicine generally, but we owe such knowledge as we possess of the Assyrian Herbal entirely to 10r. Campbell 'Thompson, Fellow of Merton College, Oxford. Whilst serving in the British Museum he enjoyed ready aecess to the many thousand tablets and fragments of tablets of the great Nineveh (Kuyunjik) Collection, and made the large and valuable series of Iists of Assyrian Plants which were published in Cunciform T'exts, Vol. XIV, London, 1902. The texts there given are entirely distinct from the medical texts published by him in Vol. XXIII of the same work.

Between 1902 and 1920 various scholars published many fragmentary texts, with translations, but the results were wholly unsatisfactory, for they either left the regetable medicines and drugs unidentified or translated the names of them haphazard. 'Thompson was the first to see that no real progress had been or could be made until the whole of the fragments of herbals and medical texts in the British Museum and 
clsewhere had been examined and published. Inpli(ates must be recognimed and sorted out, and all the fragnents which belonged together rejoined. 'To this areat work he devoted himself, and his Assyrian Herbal, or monograph on Assyrian vegetable drugs, appeared in Jondon in 1924. Ilis study was based upon the texts of 120 ('unciform fragments published by Rawlinson or by himself in the offerial editions of the British Nusemm, and on the copies of 660 medical tablets published in his Issyriam Medical Texts, Oxford, 19283, and on previous publications of merlical texts.

As a result of his studies we now know that the vegetable drugs known to the Assyrians were about 25() in number. The mincral drugs were about 120 , and other drugs, still unidentified, were about $180 \mathrm{in}$ number. 'To these must be added alcohols, fats, oils, honey, wax. and various kinds of milk (Assyrian IIerbal, p. v). A list of all the drugs at present identified is given on pp. vii-xi. An examination of the plant lists of the Herbal shows that the ancient botanists adhered in the main to a definite arrangement. 'The herbalist had sufficient knowledge to classify plants according to his needs, but he does not arrange his plants in the order of modern botanists. Ife begins with grasses. and then follows with rushes and Emphorbiacere, reasonably enough, but he groups the Papaveracere and cucurbitacere with other orders because the names for the principal plants begin with a certain comeiform sign. He scatters Compositac thronghout his series. 'Thompson says: "The more the subject is studied, the more obvioms appears to have been the great knowledge possessed by the doctors and chemists of Ninereh." When the Assyrian 


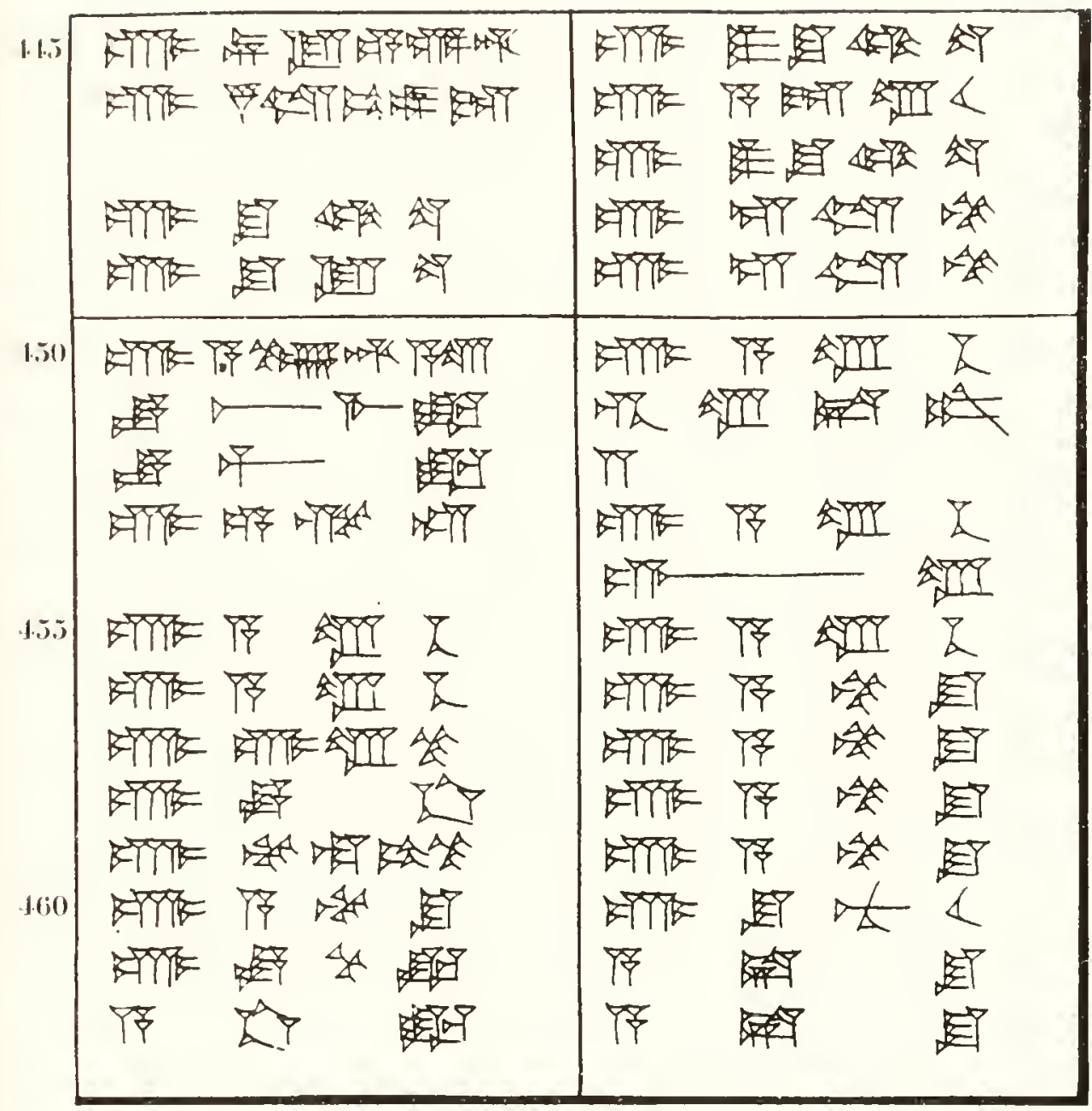

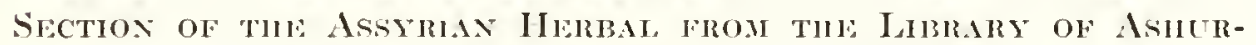

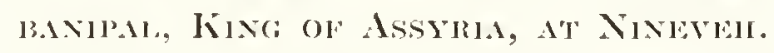

(From the reverse of Brit. Mus. Tablet No. 4:345, published by Dr. 'Thompson in C'uneiform 'Tex's, Part XIV, Plate '2S, and in his Assyrian ilcrbal, p. 21.) 

Ilerbal was complete it contained the names of between 900 and 1000 plants, but the fragments now marle avalable in their entirety show that many of these were synonyms. 'Thompeson has in a ereat measure reconstructed the Assyrian II rerbal, and, following each section of the text, he gives notes in which he discusses the names, colours and forms of the plants, and states what he belicres to be their medicinal properties. IIe shows that the names by which we know many of the plants are derived from Sumerians through the Greek and Arabic languages, and among such may be mentioned apricot, asafoetida, saffron, liquidambar, galbanum, colocynth, carob, cardamom, cummin, opoponax, tumeric, cherry, flax, nard, silphium, phaseolus, myrrh, mulberry, mandrake, almond, poppy, styrax, sesame, cypress, lupin, etc.

Here may be given an extract from the great Assyrian Herbal from a tablet (K 4:345) in the British Iuseum: in Thompson's reconstruetion the lines are numbered $4+5-462$. It will be noticed that nearly all the lines in both columns begin with the sign " 11 ," which is read "sham," and indicates that what follows it is the name of a plant or of something made from a plant. The left-hand column of such lists often contains both the Sumerian ideographs for the plants, and Semitic names and synonyms and the right Semitic names. A transhiteration of the lirst five lines of the extranct will make this clear.

\begin{tabular}{|c|c|}
\hline $4+5$ & u \%al.,u c-rish-ti \\
\hline 4.6 & 11 SHA.IAM.MI.TLK.K \\
\hline $1.1 \%$ & \\
\hline $4+8$ & $u$ shu-ul-tu \\
\hline 449 & $u$ shuu-lu-tu \\
\hline
\end{tabular}

ush-shu-ul-tu
"a-ra-ru-u
u ash-shu-ul-tu
u si-lam-mu
u si-lam-uu. 
As specimens of the Assyrian medical texts may be quoted :-

1. II a man's eyes lare full of . . . . thou shatt mix folimm (and) flower of parched com in beer and bind on; for three days to his eyes thou [shalt do this]. renewing (it) thrice daily; on the fourth day thou shalt surround his eyes with suadu (and) opium, water in ........ of clay and once, twice, or thrice his eyes thou shalt press : marrow of gayelle-bone to his eyc[s thou shalt apply]. Then in opinm thou shalt bray antimony (and) apply it to his eyes; thou shalt bray gall apples (and) apply dry to his eyes. 'Thrice raily thou shalt renew (it); thou shalt mix a paste of ma i (?), barhush ( $N$. tamarisk), seed of Kutu, ... . parched corn, Lolimm; apply it dry to his head. bind his head, and for [three] days [do not take off]. On the fourth day thou shalt take it off and shave his head: apply thy paste to his eyes, [and he shall recover]. ['Thompson, Proc. Roy. Soc. of Medicine, Tol. XIX, No. 3, p. 48.]

2. IXCANTATION FOR TOOTHACHE, which was belicved to be caused by a worm gnawing at the root of the tooth :-

After Anu made the hearens, the hearens made the earth, the carth made the rivers, the rivers made the canals, the canals made the marsh, the marsh made the Worm. 'The Worm came weeping to Shamash, rame unte ka, her tears flowing: "What wilt thou give me for my food, what wilt thou give me to destroy?" "I will give thee dried figs and apricots." "Forsooth, what are these dried figs to me, or apricots? Set me amid the teeth, and let me drell in the gums, that I may destroy the blood of the teeth. 
OBVERSE.

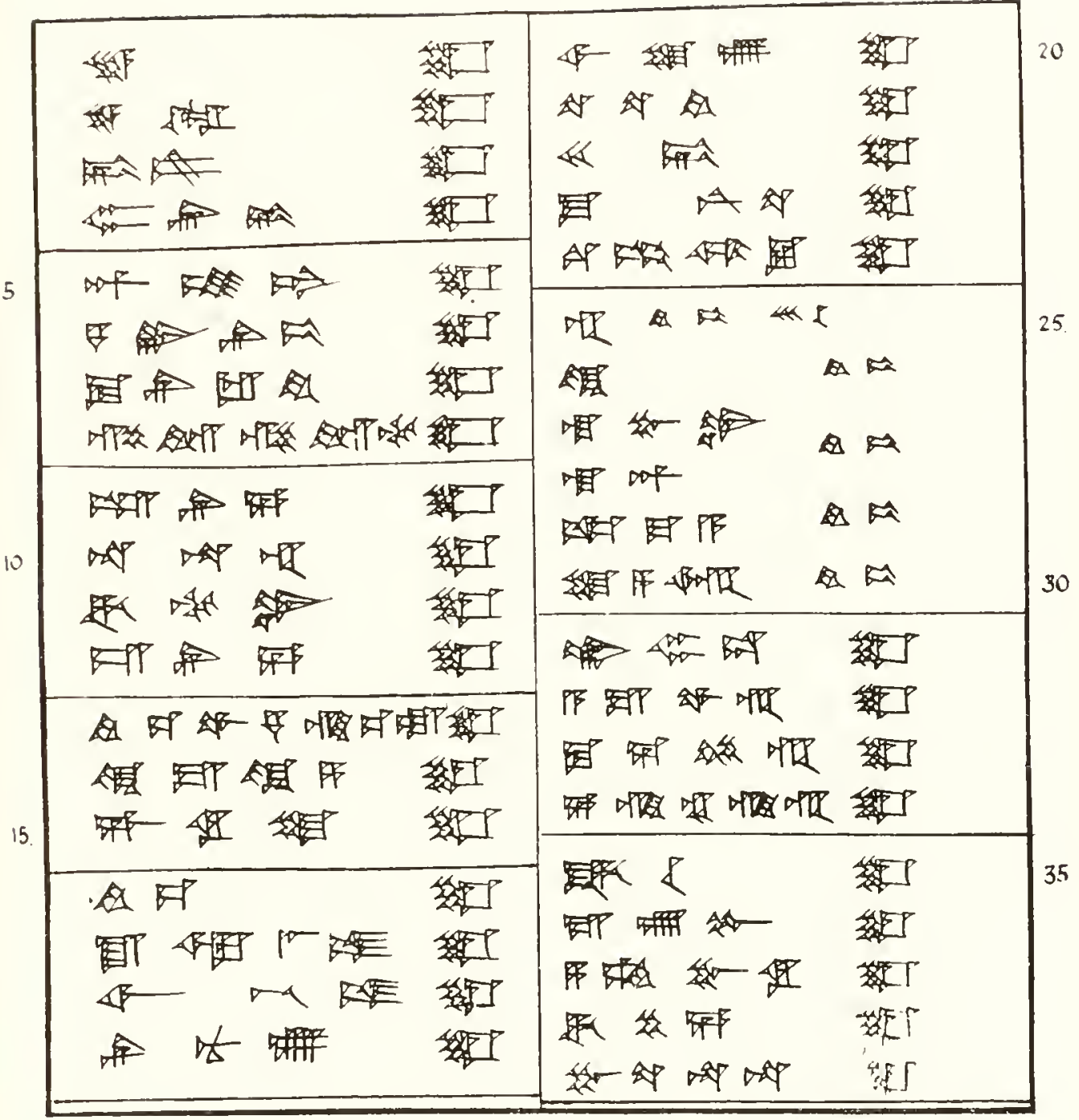

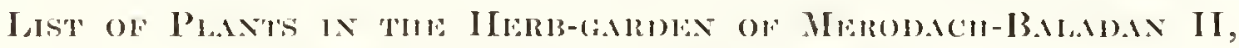
Kise of Babrox, ('ols. I .ND) II.

(From Brit. Mus. 'lablet No. Hezeg, published in Cunciform Texts, l'art XIV, Plate 50.) 

REVERSE.

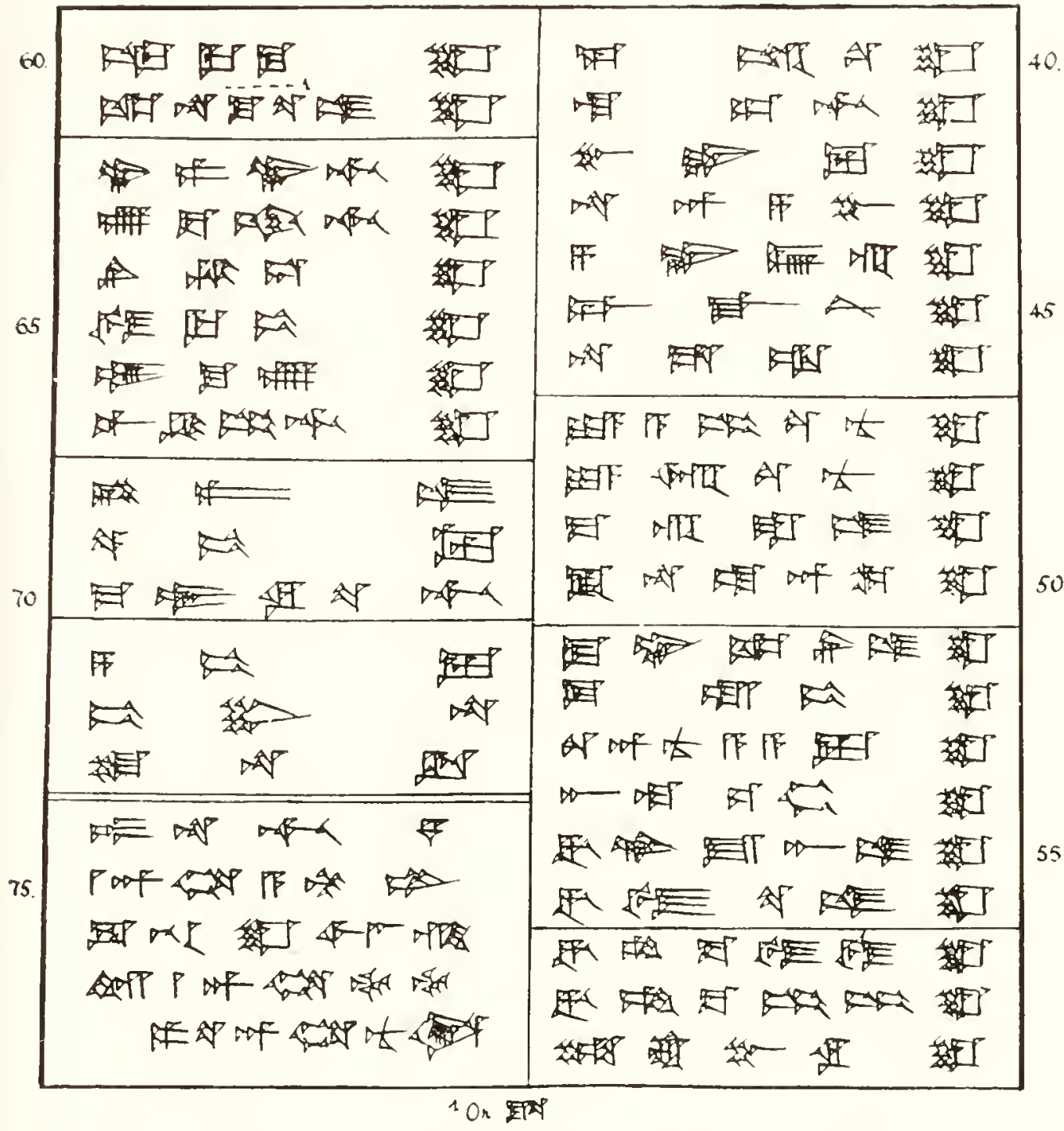

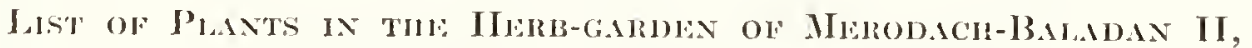
King of Babrlon, Cols. III ANH IV.

(From Brit. Mus. Tablut No. Afizen, published in C'unciform Texts, Part XIV, Plate 50.) 

and of the gums chew their marrow. So shall I hold the latch of the door." "Since thou hast said this, () Worm, may ka smite thee with his mighty fist" ! [lbid., p. 59.]

'The Assyrian Herbal makes it quite clear that those who compiled it possessed a very considerable knowledge of herbs and plants and their properties, and we must assume that they took steps to ensure that a regular supply of medicinal plants should be forthcoming. This eould best be done by establishing "physic gardens " in connection with the temples or the King's palace. Whether they did this or not cannot be said with certainty, but when we consider the great importance of herbs and plants in the Mesopotamian system of medicine, it seems very probable that they did. Now there is preserved in the British Museum a small clay tablet (No. 46226) which is inseribed in the neo-Babylonian character with a list of the plants which were in the garden of Merodach-Baladan II, King of Babylon, B.C. $721-\gamma 10$ and $703-\gamma 02$. It gives the names of 73 "garden-plants," arranged in groups in two eolumns. 'The sign which comes at the end of nearly every line indicates that the plants were strongsmelling (the onion is mentioned!), or that they emitted pleasant aromatic odours. 'This list was made for or by one Marduk-shumiddin, who describes himself as a worshipper of Marduk, from an older copy which, judging from the remark repeated in small characters in lines 25-30, was illegible in places. 'The docket gives the name of "Marduk-apal-iddina, the King," and the following line states that the copy was "written, revised, and correct according to its original." It might not be strictly accurate to say 
that the tablet gave a list of the contents of Merodach-Baladan's "Physic Garden," but there is no doubt that among the plants mentioned in the list are many that were used in medicine. Where the garden was situated camnot be said, but it was probably on the west bank of the Euphrates near the town of Hillah.

The great King of Assyria, Sennacherib, B.C. F05-681, also laid out gardens and parks round about Ninereh. On one of his inscribed prisms in the British Muscum (No. 103,000) he says: "I laid out gardens above and below the city. I planted for my subjects, products of the mountains and of all countries, all the herbs of the land of Khatti, and murru plants, which flourished more than in their own country, all kinds of mountain rines, all kinds of foreign fruit trees, herbs and sirdu trees for my subjects." And this King secms to have introduced the cotton tree into Ninereh, for he says: "They clipped the trees that bore wool. and they shredded it for clothing."

Among the plants known to the Assyrians was one which appears in the famous Epic of Gilgamish; it was called "Shibu issahir amehı," i.e. "the old man becometh young [again]." The immortal T'taNapishtim told Gilgamish that it grew at the bottom of the sea, and that it would confer upon him immortality. Gilgamish weighted himself with stones, and let himself down on to tho bed of the sea thromgh an opening in the floor of his boat. Ho fonnd the plant, phucked it, and assended into his boat with it. Whilst he was on his way hack to keceh. Citgamish saw a pool of cold water. and sctting the plant down he dived into the water and bathed. Whilst he was 
doing this a serpent discovered the whereabouts of the plant through its smell and ate it up! 'Thus Gilgamish lost his last chance of becoming immortal.

Thanks to the magico-medical texts which have been published in recent years it is now possible to describe the method of treatment employed by the Babylonian and Assyrian herbalist and physician. When a man fell sick in his house, sooner or later a messenger was sent to "fetch the doctor" from the temple. The $A s t$, or doctor, no doubt questioned the messenger fully, and when he had learned from him details eoncerning the sick man, he took his medical box and stocked it with the drugs, and perhaps instruments, such as a knife and a tube, which he thought would be required by him. Then with his staff or rod of office in his hand, and his box, he set out to go to the house of the sick man. But he did not go alone. He took with him a priestly official, whose title was "Ashipu," and who was learned in exorcisms, spells and ineantations, and another official who was known as the "Bāru" or Seer. 'This last was skilled in the knowledge of omens.

As the three men made their way to the house of the sick man, the Bāru watched every person, animal or thing which they met, and proceeded to deduce omens from what he saw. He told the Ashipu what the omens portended, and this man began to recite the incantations which he thought would arert evil from the sick man. When the trio reached the house and went into the room of the sick man, the Asu examined him carefully and made his diagnosis, and meanwhile the Banru continued to deduce omens from the state of the various members of the patient's body, whether his head was hot, or cold, or moist, whether there was 
foam on his lips, whether he was lying on his right or left side, or on his back, etc. As he told the Ashipu what such things portended, this official recited the incantations that were suitable. Meanwhile the Asu had decided what medicines were to be used, and when he had made then ready and began to administer them, the Ishipu continued to recite the incantations which were to drive out of the patient's body the devils or evil spirits that were the causes of his sickness. Thus medicine and magic went hand in hand, but any good effect which the medicines might produce was ascribed to the magical power of the incantations, and to the wislom of the Bäru, who had read the omens rightly. In cases of prolonged illness the patient was removed to the temple, where a special chamber called the KunuU was provided for the reeeption of the sick, but the relatives of a patient were held to be responsible for his maintenance. Here in the Kummu chamber magical rites and ceremonies for the bencfit of the sick were carried out in great detail. Magieal signs and symbols and names were written on the walls, and series of prophylactic figures were employed to protect both the patient and the chamber from the attacks of devils. These figures were placed in boxes of burnt brick underneath the pavement, and the boxes were lined up against the walls, the open side of each box facing towards the ('entre of the chamber, the figures thus being on guard, as it were, orer the living space. The figures were all ol unbaked clay. Some of them had human bodies with birds' heads and wings, some of them were of males, and if nude were generally ithyphallic, or wholly obscene, and cat-headed figures, and figures of snakes, dragons, ete., were also found at $\mathrm{Ur}$. 
Incantations were recited over these figures, magical names were written on their hips, and a certain group of seren of them represented the seven Apkallu, or sages who lived before the Flood, and were the first to teach men incantations against siekness. Mr. Sidney Smith of the British Museum has discovered the ritual texts which deal with the prophylactic figures, and he has published translations of them, with notes, in a valuable paper on the figures actually found at $\mathrm{Ur}$ by Mr. C. I. Woolley in Joumal Royal Asiatic Society, October 1926, p. $689 \mathrm{ff}$. 


\section{VIII}

THE GREEK IIERBAISS

Ix the preceding pages the history of the IIerbal in Egypt and Mesopotamia has been traced from the beginning of the third millennium B.c. to the reign of Ashurbanipal, King of Assyria, B.c. 681-668. It has also been shown that the system of medicine in use in those countries had much in rommon, and that the herbalists and physicians in both countries believed that both their craft and their medicines were of divine origin. Of the history of the IIerbal after the Fall of Ninerch, which we now know (thanks to Mr. C. J. Gadd) took place B.c. 612, nothing is known, but there is little doubt that the medieines used in Egypt became known in Nubia and Northern Ethiopia and to the peoples of the Mediterrancan, and those used in Babylonia and Assyria found their way into Persia, Armenia, Syria and Palestine. Throughout all these countries the belief that sickness and disease were caused by devils and evil spirits was general.

The IIellenes (Grecks), like the Sumerians and Egyptians, believed that the gods were the first herbalists and physicians, and that the art of healing was taught to man by them. Their first great god of medicine was Asklepios or Asculapers, the son of Apollo and the virgin Coronis. He was born in Epidanrus, and is said to have flomrished about B.C. 1250. He learned his art from Cheiron, and was so 
snecessful in healing discasc, and in raising the dead, that '/eus became jealous of him and slew him with a thunderbolt. II and his sons Marchaon and Podalirius are mentioned by Homer (Iliud, ii. 7:31). He carried a staff, with a serpent, the symbol of renewed life, coiled round it. Hyoicia, the goddess of health, was his damehter. IIe was worshipped in Rome under the form of a snake at the begimning of the third eentury B.e. There was never any suggestion that he wrote books of medicine. An ancient tradition says that Esculapius was a native of Memphis in Egypt who emigrated to Greece, and that he introduced the knowledge of medicine into that country. Another legend says that when administering medicines or using the knife he recited incantations in order to make his drugs more elfective.

But the real founders of Greek medicine and the compilers of the Greck Herbals were not the priests of Esculapius, but the lay herb-doctors and physicians who were called "Asclepiadx." Like the wandering "Hakim " who is met with in towns and villages in Mesopotamia and the neighbouring countries at the present day, the Asclepiadxe earned their living by wandering about from place to place, and healing the sick folk wheresoever they found them. It is interesting to find a woman among the recognized herbalists of this carly period, for Agamede, daughter of Augcias, and wife of Mulius, was fanced for her knowledge of the healing powers of all the plants that grow upon the earth. She is mentioned by Homer (Iliad, xi. 739). Homer also mentions the Egyptian queen Polydamna (Odys., iv. 238), who gave Helen a drug (opium?) which woukl soothe every grief and abate anger. 
'The founders of many of the great Greck Schools of Medicinc owed theix learning in a great measure to the ligyptians. 'Tususs of Miletus (B.c. 6:39-5+t). the founder of the Ionic School, was a pupil of Egyp)tian priests. PYTHagoras of Samos (13.6. 580-489). the founder of the School of Crotona. Was a pupil of Un-nefer, a priest of Icliopolis. Hiplock৯Tes (B.C. 460-3\%5) of Cos, the "Father of Medicine," the sceond of this name in a family of rery distinguished men, and the fonnder of a system of scientific medicine, derived a great deal of his learning from the Egyptians. He was the son of the Asclepiad Heraklides, who was the serentecnth in descent from Asculapius, by the midwife Phacnarete, who was eightecnth in desecnt from IIercules. He was the first to banish magic and superstition from medicine, though eren during his lifetime many practitioners, whilst using his remedies, resorted to magic and incantations to give geater effect to them. The drugs which he used-between 300 and 400 have been enmmerated-were chicfly vegetable in character, but he employed copper', alum and lead in his medicines, and even common articles of food. 'There is no evidence that he rompiled a IIerbal, and therefore he most probably used the lists of plants which were known to 'Thales and Pythagoras when in Egypt.

'The first Greck IIerbal of which we have any mention ronsisted of lists of plants and their habitats. with short statements concerning their medicinal propertics. 'This was compiled by Diocase Carsters. who was born at Carystus in Euboa, probably in the first half ol the fourth antury 13.c. He bolonged to the Dognatic Sichool of Medicine which was lomnded by 'Thessalus (13.(. 3s()), Draco the physician and 
others. His Herbal is no longer extant, and of most of his other works only the names are known.

The great philosopher Aristotis, the "Stagirite" (13.c. 384-322), the son of Nicomachus (a descendant of Machaon, a son of Asculapius) by his wife Phastis, was thought to have compiled the list of over 500 plants (De Plantis) which is usually included with his works. but modern erities attribute the list to a later writer, perhaps 'Theophrastus of Eresus.

Theopirastes ('Tyrtanus) was a native of Eresus in Lesbos; he was born about B.C. 372 and died in 285. He wrote two books on botany, and describes in his IHistoria plantarum over 500 plants; some of his statements are based on the knowledge of plants which he acquired at first hand during lis travels, and others, especially those on foreign plants, from information supplied by caravan merehants. He may be regarded as the first seientific botanist, and his work eontains parts of the oLDEST GreEK HERBAL known. For the text of the Historia see Wimmer's edition (Tratislarix, 1842) and Sir A. F. Hort's Theophrashes : Enquiry into Plants, London, 1916.

IIErophilus was a native of Chalcedon in Bithynia, and a prominent nember of the Medical School of Alexandria; the dates of his birth and death are unknown, but he probably flourished in the first half of the third eentury B.C. He was severely critieized for administering large doses of vegetable compounds to his patients, and for the invention of heterogeneous mixtures of drugs. His work on plants, which is mentioned by Pliny (XXY. $\$ 5)$, is no longer extant.

Annzeas of Carystus, who was physician to Ptolemy IV. Philopator, wrote a work on plants, which is now lost; whilst in attendance on his master 
in his tent, 'Theodotus the Atolian, who had hidelen himself therein. killed him by mistake for the King (ahout 13.('. 217).

Nicien (the Scxtins Niger of l'liny) flomrished about B.(. 30 and wote a IIerbal in Greek which is now lost.

CRATEUAs was a equat horbalist and collecotor of plants, and physician to Mithridates rT. Eupatop (B.c. 10 6:3) of Pontus, who was also a ereat herbalist, and famous for his skill in destroying people by poison. Cratenas wote a Herbal in which he gave drawings of all the plants. Each drawing was preceded by the name of the plant and followed hy a description of its use in medicine. He was the lirst to illustrate the IIerbal. Siee Mr. ('. Singer's article on the "Juliana Anicia Codex" at Vicmna (written about A.1. 5l\%), and the possible restoration of several of the drawings of Crateuas in Joumal II llenic Studies, Vol. XIVII. (192\%), p. 4 ll.

All the Greek IIerbals and medical works witten between about 13.C. 300 and B.C. 30 by the great botanists and herbalists of the School of Medicine of Alexandria were hased upon the lists of plants and medical works of the Eeyptians. The Sumerians and Egyptians made provision for receiving patients in their temples, and quarters for sick folk existed in the famous Muscum at Ilexandria. 1)uring the ptolemaï period a considerable amomnt of knowledge of Simmerian and Babylomian neclicinc must have fonmel its way into ligypt, as a result of the "ampaigns of Alexander the Great in Western Asia in the founth century 13.C.

Panpulas, a Greck herbalist who practised in Rone, wote a Herbal in which the names of the 


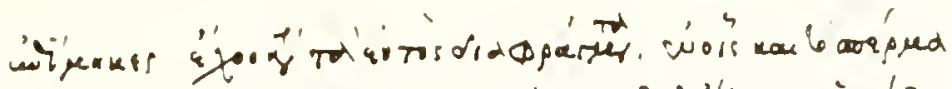

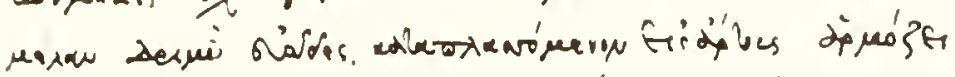

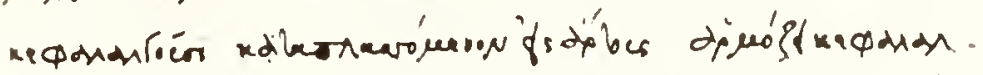

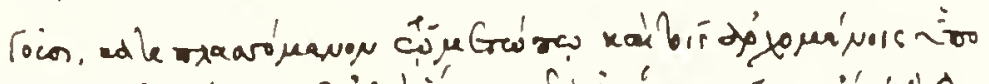

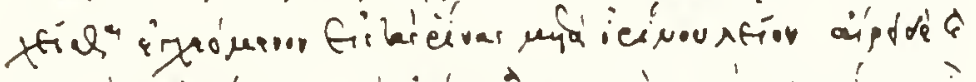

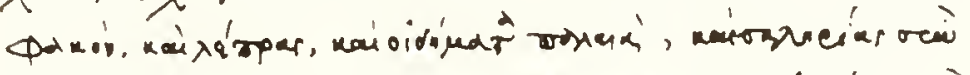

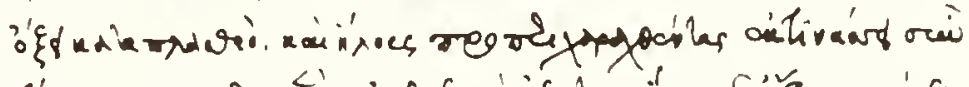

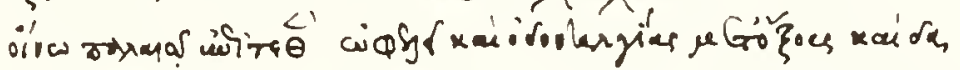

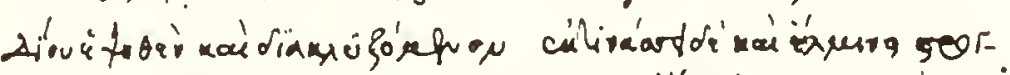

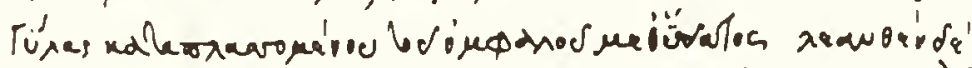

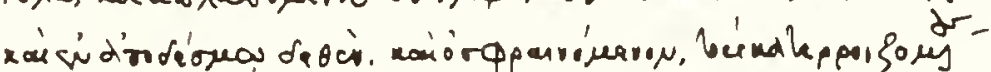

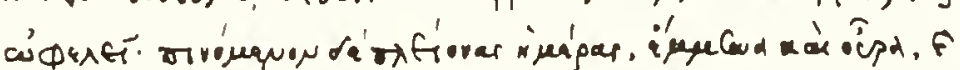

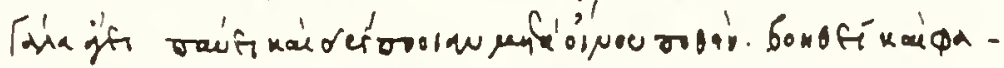

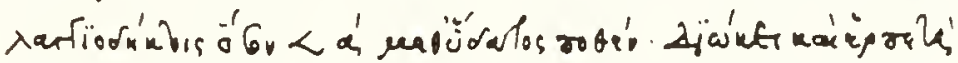

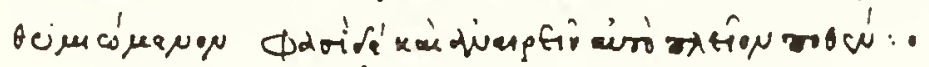

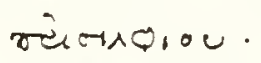

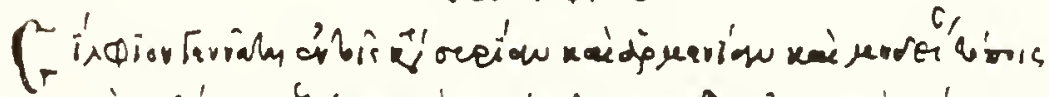

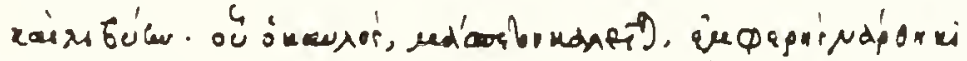

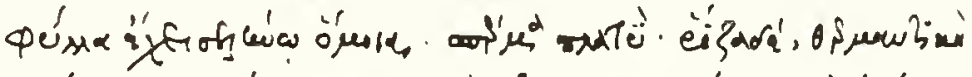

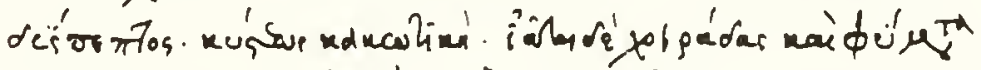

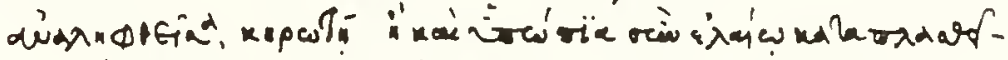

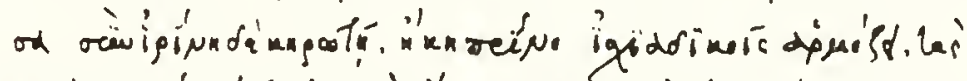

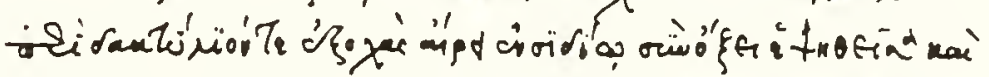

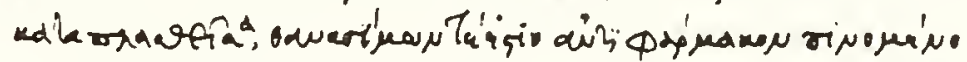

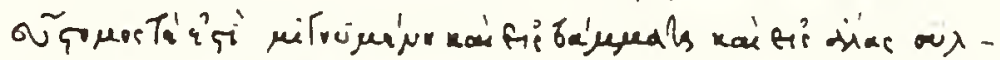

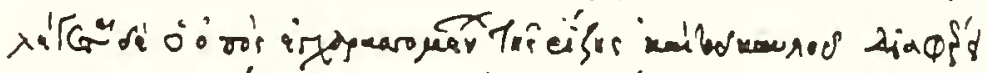

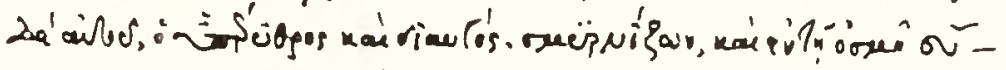

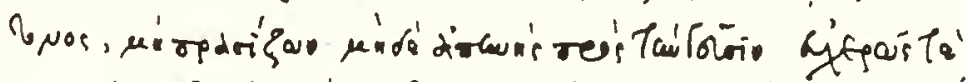
дін

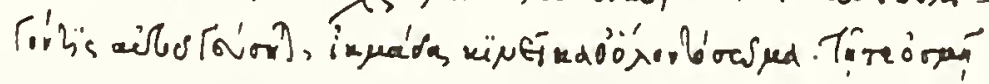

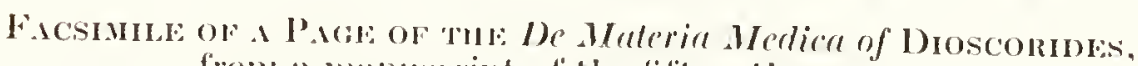
from a manuscript al the filteenth ecolury.

'The lower larlf of the page contaims a description of the Silphiom

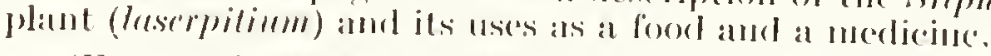

(From Brit. Mus. Marl. MS. No. 5679, fol. 116u.) 



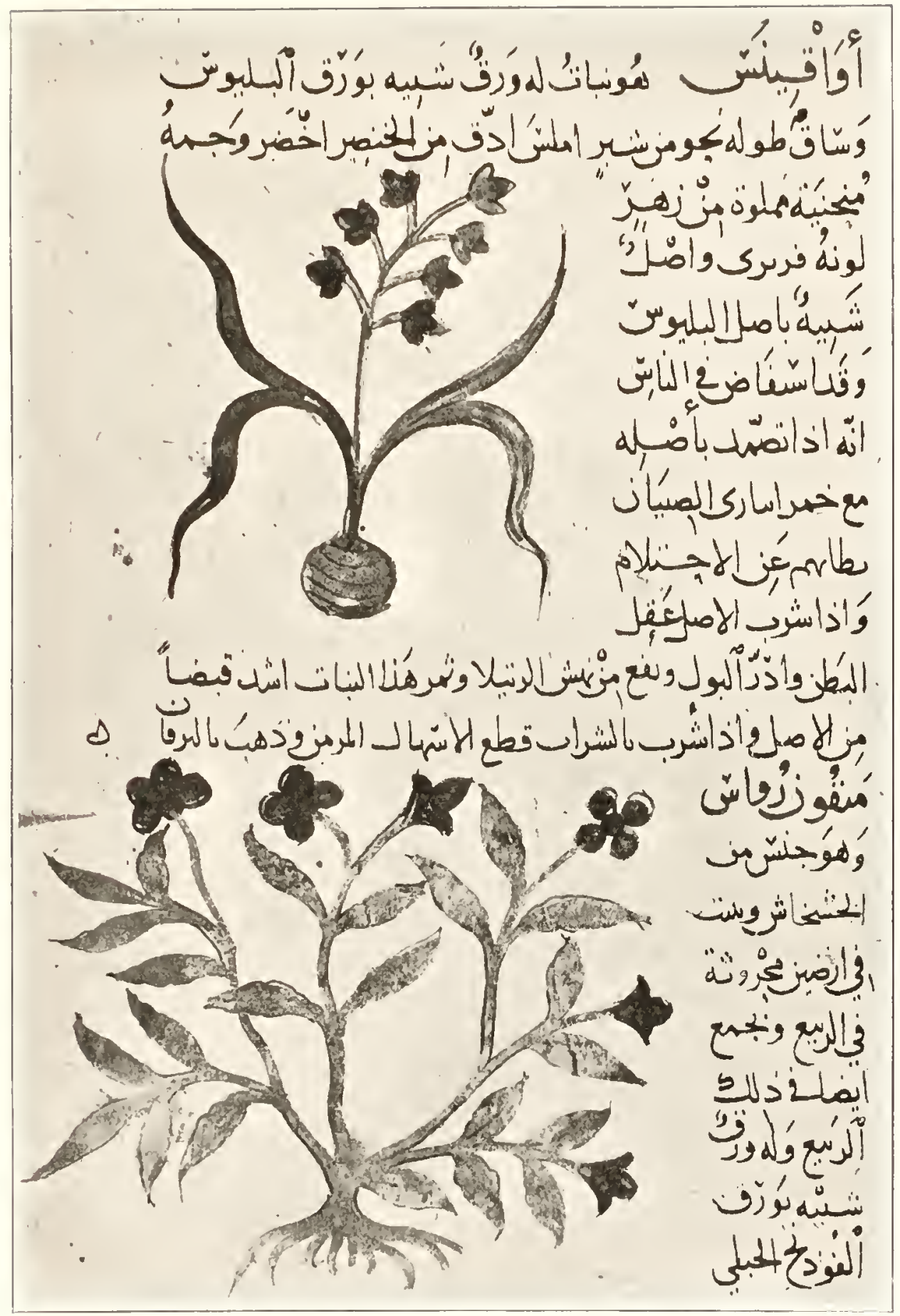

Facsinha of a Pagle of the Aranic Vension of the De Materia Medice, with coloured drawings of plants from a manuscript of the twelith century.

The text describes the Awakinash phant, and the mankmi-rmish, a plant of the poppy chass.

(From Brit. Mus. Ms. Orient. No. 33:366, fol. 133a.) 

plants were arranged alphabetically; portions of it are preserved in the "Juliana Anicia Codex" mentioned above. Galen mentions Pamphilus, and aecuses him of describing plants which he had never seen!

Menecrates ('Tiberius ('laudius), physician to the Emperor Tiberius (A.D. 14-3i), wrote a Herbal, which is lost. IIe was the inventor of Diachylon plaster.

We have now to eonsider the work of one of the greatest, if not the greatest, of the ancient herbalists, riz. Pedaxits Diosconides (or Dioscurides), who was a native of Anazarba in Cilicia Campestris, and flourished in the early part of the second half of the first eentury of our era. He was one of the physicians attaehed to the Roman Army in Asia, and he collected a great deal of general information about plants at first hand. He owes his fame rhiefly to his work.

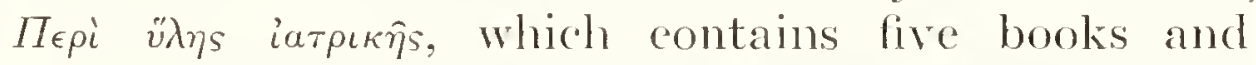
is commonly known as De Materia Medica. The Greek text of this treatise has been published by Wellmann in the third rolume of the eollected works of the great herbalist (Bcrlin, 1914). A very useful summary of the results of recent study of the works of Dioscorides will be found in Singer, studies in the II istory and Method of S'sirmer, Tol. II. p. 6-t. Oxford, 1921. Dioscorides travelled extensively in cireece. Italy, Comany, Gaul, spain, ctc., and as a result was able to discuss and describe about foo plants. In his Iferbal that is to say, that portion of it which deals with plants-he gives the name of the plant and its Greck synonym, a description of it, its labitat and clirection for its preparation as a medicine, and its medicinal effects. His Herbal is, in fact, a laborious 
compilation made from the works of Hippocrates, 'lheophastus of Eresus, Erasistratus, Andreas, Niger, Crateuas, Nikander and many other scientific botanists and herbalists. Among the drugs mentioned in his Pharmacopocia which are still to be found in the modern Pharmacopocias of Europe are:-almonds, aloes, ammoniacun, aniseed, belladonna, camomile, cardamoms, cateehu, cinnamon, colchicum, colocynth, coriander, crocus, dill, galbanum, galls, gentian, ginger, hyoscyamus, juniper, lavender, linseed, liquorice, male fern, mallow, marjoram, mustard, myrrh, olive oil, pepper, peppermint, poppy, rhubarb, sesame, squill, starch, stavesacre, storax, stramonium, sugar, tercbinth, thyme, tragaeanth, wormwood. Two centuries later a number of synonyms were added to the Herbal of Dioscorides, and many figures of plants derived from illustrated Herbals, one being that of Cratcuas. From this Recension of the Herbal of Dioseorides all the remaining manuscripts of the work have been copied, more or less completely from another Recension of the Herbal in which the synonyms were arranged alphabetically. ORIBAsits of Perganus (A.D. 3.5-403) based many portions of his works on it. This is not the place to trace the history of the transmission of the Herbal of Dioscorides from the fourth to the sixteenth century, which has been so admirably done by Mr. Singer in Jommal Hellenic Studies, Vol. XLVII. p. 2+ fl. It is sufficient to say that for more than thirtecn renturies it was one of the principal text-books of herbalists and physicians throughout the eivilized world.

'The Greek IIerbal assumed its final form in the

1 About 1330 of the plants known to Ilippocrates are mentioned by Dioscorides. 


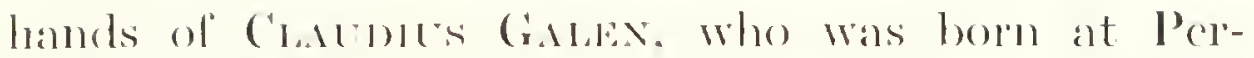
gamms in Moysial abont .1.1). 130); he was the son of Nicon, an arehited. He travelled cxtensively in Palestine and Asia Minor, and studied plants, and then set out to find the gagales stone, the use of which was believed to aure gout, cpilepsy and hysteria. He wrote books on many subjects, and is said to have been the author of nearly 400 works! (of the 27.5 medical treatises attributed to him, 833 are genuine. 19 are doubtful and ts are lost. About $8: 3$ of his works are extant. and of these some 80 exist only in manuseript. 'The most complete edition of Galen's works is that of Kïhn in 220 rolumes; a complete translation from the Greek of the entire works of Galen has never been made. Galen enjoyed great reputation as a philosopher and a medical teacher and law-girer. 'Thoughout the whole Middle Ages this reputation continued undisputed, and, according to Baas, "by it he was the lord and master of medicine for fifteen hundred years." The Iterbal of Galen is

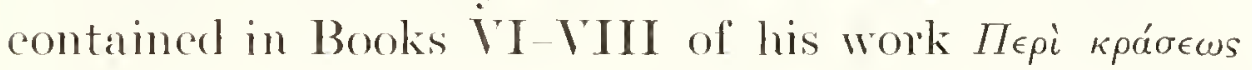

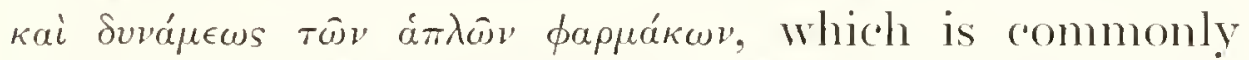
spoken of as De Simplicibus. These contain a list of drugs and their uses. A paragraph is given to each plant, and after its name come its synonym and its habitat: sometimes balen gives a description of the plant itself. and he usually ends the paragraph with a statement as to its nse in medicine.

Galen's work was so romplete, and in a way so final. that no Greek or Roman botanist attempted to supersede the Dre Simplicibus by a work of his own. On the other hand, many herbalists based their treatises on plants on Galents IIcrbal, and of them the most prominent was ()mansiest of l'oreamms 
(A.D. 3026-403). IIe was a pupil of Zexo at Alexandria, and becanne physician in ordinary to Julian the Apostate. But when he failed to heal the wound which his master received during the Persian ammpaign, he lost his position and his possessions. If wrote several works, and in his Collecta Medicinalia, or "Medical Compendium," he quotes not only wellknown and famous witers like Hippocrates, Gaken, Dioscorides and lDiocles, but also lesser known botanists like Dieuches, Philumenus, Mnesistheus, etc. He was well acquainted with syphilis and gonorwoea, and unceasingly proclaimed the value of dietetics and gymmastics. 


\section{IX}

\section{TIIE LATIN HERIB.LS}

Here must be mentioned two works which, though not Herbals in the true sense of the word, may be regarded as such, viz. the De Re Rustica, whieh in its earliest form was written by Marcius Porcius Cato Cexsorrates (B.C. 234-149), and the lengthy work on "Remedies derived from the Garden Plants" which fill Books XX-XXV of Pliny's Natural History. Cato's work contains a eonsiderable number of native medieal prescriptions of an old-fashioned character, and the magical spells or songs which were to be chanted whilst the medicines were being administered, e.g. "Huat, hanat, ista, pista, sista, damniato damnaustra." The following extract will give an idea of the eharacter of Pliny's Herbal.

"Cichoriula or Chreston, otherwise Called Paxcration, or ambula : 12 remedies. Wild endive or cichorium has ecrtain refreshing qualities used as an aliment. Applied by way of liniment, it disperses abscesses, and a decoction of it loosens the bowels. It is also very beneficial to the liver, kidneys and stomach. A decoction of it in vincear has the effect of dispelling the pains of strangury; and, taken in honied wine, it is a cure for the jaundice, il' unattended with fever. It is beneficial, also, to the bladder, and a decoction of it in water promotes the menstrual discharge to such an extent as to bring away the 
dead foctus even. In adklition to these qualities, the magicians state that persons who rub themselves with the juice of the entire plant, mixed with oil, axe sure to find more favour with others. and to obtain with greater facility anything they may desire."

But the Italians of the third rentury after Christ were satisfied neither with their own native and simple prescriptions, nor the more scientific remedies of Dioscorides and Galen and works like the merlical

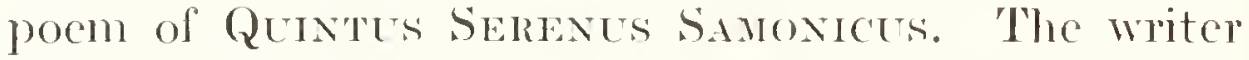
insisted on the value of magical formulas and the numbers :3, $\%$ and 9, and revired the anmulet, which was derived from the Gnosties of

(1) .1312 .16 .21$) .13 \mathrm{R}, 1$ BRAACADABR

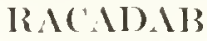
ACADA (CII)

$\lambda$

(ㅁ) MBRACADABRI

IBR.IC NDABR ABRA(C) DIS IIBR.TC.ID. ABRAC NI) ABRAL'. MBRIC ABRA AlBR MIS $\lambda$ the Basilidian sect, and is here qiven in its two principal forms. One or other of them was to be written on a piece of paper and folded in the form of a cross. The paper was to be homg round the neck by means of a cord made of a special kind of errass. and to lic on the naked flesh of the person who was suffering from any kind of ferer for nine days. At midnight on the nintlo day the pationt was to rise up and go to a river or rumning stream, and at the first glimpse of clawn he was to throw the papere into the stream. 'The magir letters were supposed to draw the ferer spinit into the paper, which the river womld warly towarks the rising sun that it might be bomed up hy his rays.

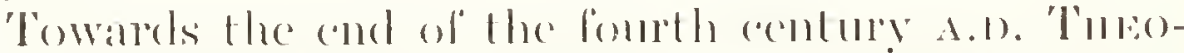

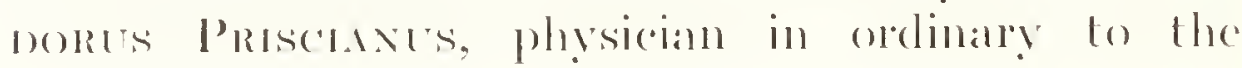


Emperor Gratian, wrote a llerbal, and laucus Aperenes produced his IIebraimm a little later. 'The De Simplicibus of Galen and the De Malerin Mediea of Dioscorides were tramslated from Greek into Latin at the end of the filth or the begimning of the sixth century, and during the suceceding centuries various Recensions of them came into being, and short medical works by other writers were incorporated in them. 


\section{$\mathrm{X}$ \\ 'THE HERBAL IN SYRIAC}

Fon nearly four centuries the Alexandrian School of Medieine (founded about B.C. 260) sent out into the countries round the Meditcrrancan scientific herbalists and botanists, skilled anatomists and wise and learned physicians. Alexander the Great had made Alexandria the greatest trading eentre in the world, and the Ptolemies, his suceessors, made its Medical School to excel all others in learning. The discoveries made in Alexandria by the physicians who dissected the dead and vivisected the living in pursuit of the knowledge of the secrets of Nature were quickly made known to the Jewish physicians in Jerusalem and Damaseus, and other cities on the great cararan roads leading towards the East. Little by little the knowledge of Greek medicine and the Herbals of Dioscorides and Galen became known in the literary cities of Amid, or Diyarbakr, and Edessa, and before the elose of the fifth century A.D. translations of Greek medical works began to be made into syriac. 'This is proved by a statement of Bar IIebracus in his Chromicle (ed. Bruns and Kirsch, Lcipzig, 1789, p. 622), which reads: "And Sapor (I., A.D. "240-273) built for himself" a city which was like unto Constantinople, and its name was Gundhī Sābhōr (Bēth Lapāt), and he settled his Greek wife therein. And there came with her skilled men from among the Greek physicians, 


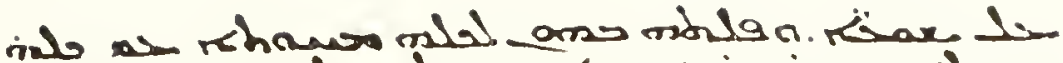

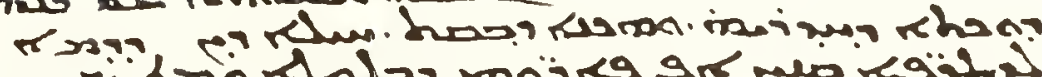

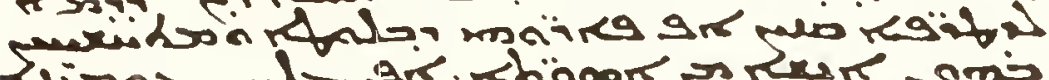

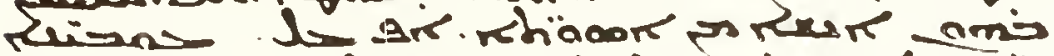

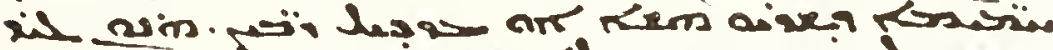

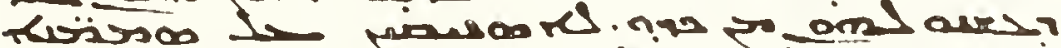

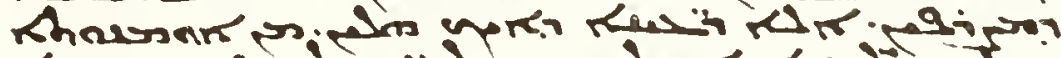

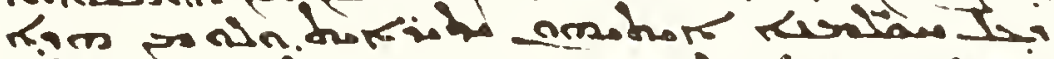

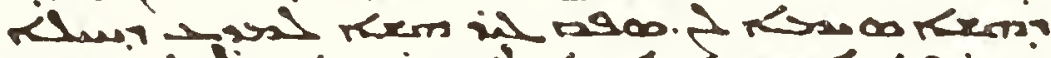
2yon.

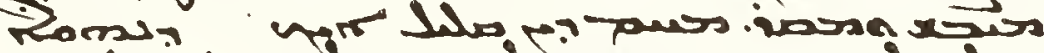

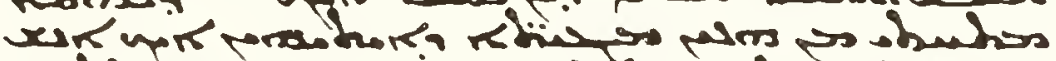

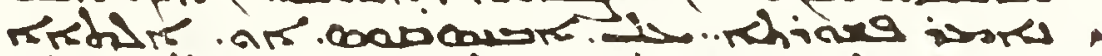

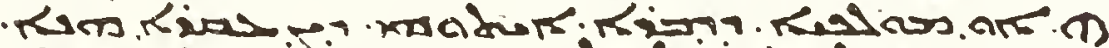

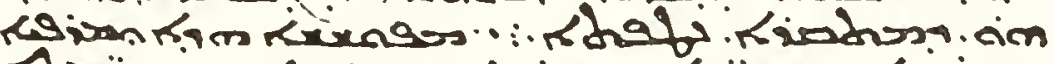
Apir Kirasonksizson Klïas Kinizan

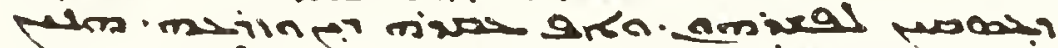

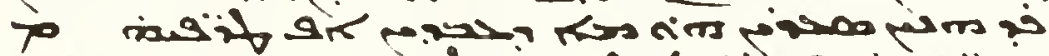

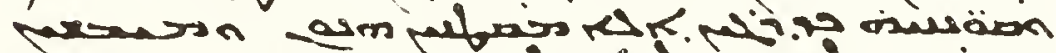

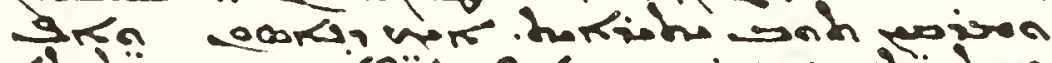

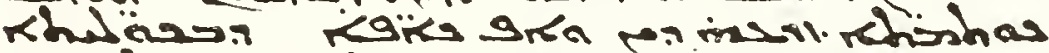

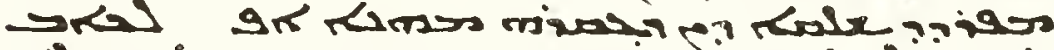

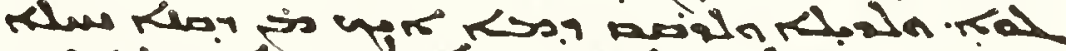

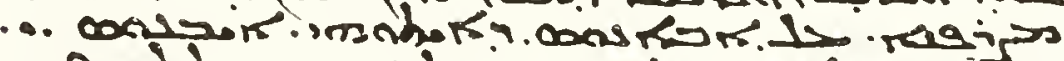

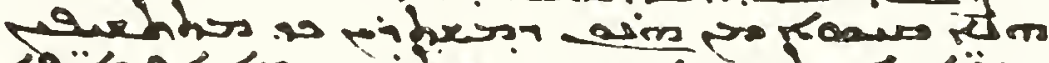

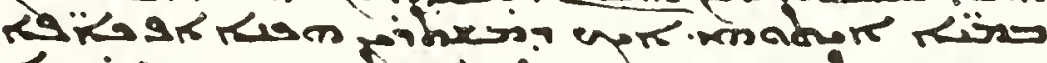

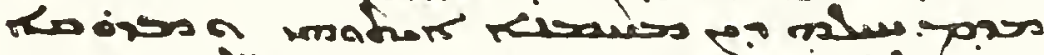

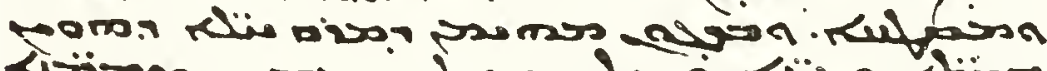

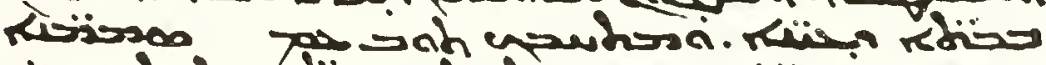

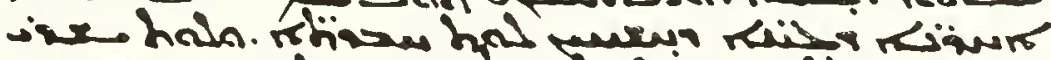

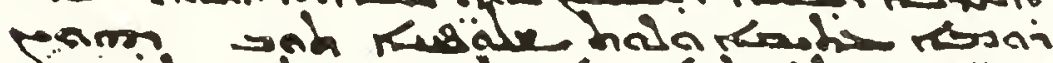

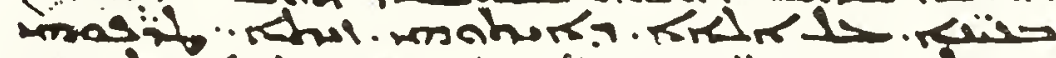

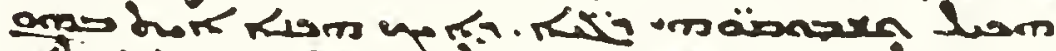

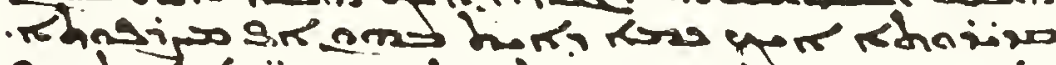

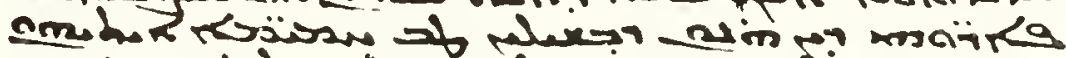

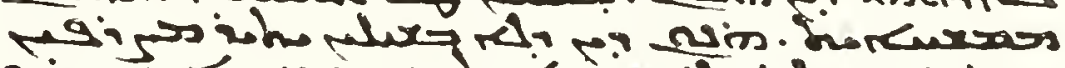
om $\because$ Kurs s.madnok.

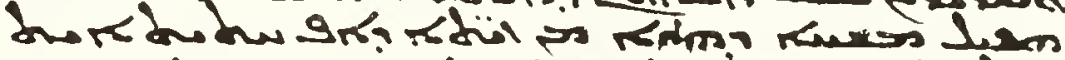

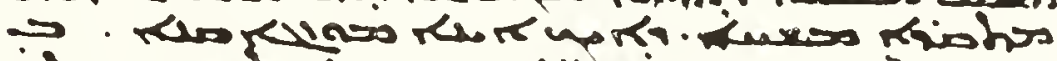

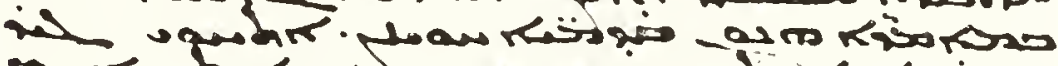

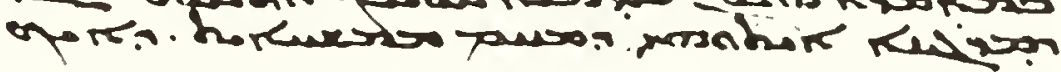

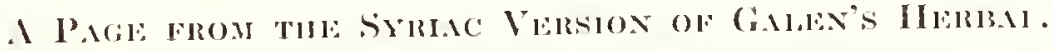

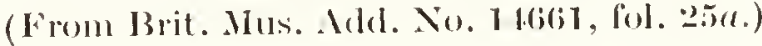



and they somed the system ol medicine of Ilipporates in the Fast. And there were also execllent Sylian

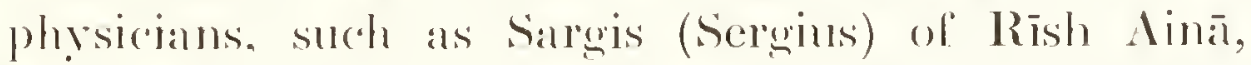
who was the first to transtate the philosophical and medical works of the Gecks into syriac. . Cossyōs (i.e. Gesius l'etrems, who flomrished in the reign of the limperor " /eno) translated his book from Gireck into svriace" Bar Ilebreus mentions several Syrians who wrote medical works in their native tongue. But most of their books ane no longer extant. As to Sergius of Rish dinā, we know that he was a good Greck scholar, and well versed in the philosophy of Aristotle; he was Arehiater in his native town. 'The British Muscum possesses copies of some of his translations from Galen's works, and in Add. $14661 \mathrm{wC}$ have a Syriac version of Books VI-VIII of his De Simplicium Medicamentornm, which may be regarded as a Syrian Herbal. 'This manuscript is one of the famous Nitrian Collection and was written in the sixth or serenth ecntury: a reproduction of a page of it is here given. In the text Galen deals with the plant hibiscus (Malia officinalis), ābānōs, or cbony wood, and the olive tree.

In 1889 I found among the Nestorians at Mōsul an ancient manuscript of a great Syriac work called "Kethābhā dhe Sammānē," or "Book of Medicines." I was able to obtain a copy of this work, and it was subsequently published with an English translation by the Royal Society of I iterature (see Budge, Syrian Anatom?, Pathology and Therapertics, 2 vols., London, 191:3). The first part of the book contains translations from the (iveck, and is clearly based upon the writings of Dioscorides or Gaken, in fact deals with medicine from the scientilic point of view of the 
Grecks. 'The second part includes a large number of native prescriptions, many of which were taken from the native medical works of the Babylonians and Assyrians, and curionsly enomeh have much in common with the prescriptions given in the vibers Papyrns. Spells and incantations were, of course, used frecly.

'The following are examples of the prescriptions in the Syriac " Book of Medicine."

1. The GREat ANTIRA medicine, which is to be nsed for aitments of the throat, and which is to be blowen into the month in the form of a diy poiceler.

'lake in equal quantities:

C'rocus, Root of mountain rose, Ammoniac, Sivallowwort, Pyrethrum, Peppercorns (lomg and round), liquorice root, Purple balaustion, Rose (yellow) leaves, Glaucium, Phocniceum, Wood lettuce, Incense plant berries, Crocus root, Green gall nuts, Green myrobalanus chebula, Lycium, Glaucium, Persian solhié, Pomegranate rind, Ferns, Aloes, Acacoia, Indian salt, Daucus gingidum, Nared, Amomun, Ginger, Anisced, Seed of rock parsley, Samterīn, Salsola, Cardamons, Reed of incense plant, Iitharogrum, Arsenic, Krōkōmaghmã, Costus, Myrrh, Dog-excrement, Verdigris (?), 'lamarix, Caryophyllus aromaticus, Vine mould, Seed of roses, Balsam bark and Cassia.

Pomad all these woll losether, reduer them to a powder, and apply somelimes in the form of a powoder, and sometimes mided acith home'y in the form of a gargle. 
2. I medicine for ganswent in the momth.

Verdigris, Pyrethrum, Persian salt, 1 drachm calch.

Ginger, Bumt peppercorns, Pilalpon, 2 drachms cach.

Crush to a powder, dip thy finger in it and rub it on the lesth and gums. Then dip a strip of linen in rinegar, squerse il dry, and dip it in the powder, and lay the strip on the place where the boils are. 


\section{XI \\ TIIE IIERBML IN ARABIC}

'Tne pre-Muhammadan Arabs first became acquainted with the Greek IIcrbal and Greek medicine through the Jewish teachers of medicine who had studied at Alexandria, and the Syrian Christians of the famous School at Edessa. When the Nestorians became all-powerful in this School, the Government disbanded the pupils and closed it. It was reopened by Bishop Ibas in A.D. 435, but was finally dissolved by the Emperor Zeno in A.D. 489. The pupils fled to Nisibis, where Bar-Sāwma founded another School, which flourished for a considerable time. From the fifth century onwards the Syrians translated Greek medical works into Syriac, and from these translations the Arab physicians made translations into their own language. The most important of these were: GEorge, the son of Bokht-Ishô, physician to AlMansûr the Khalifah in the eighth century; Gabrien. physician to IIñrūn ar-Rashīd, who died at Baghtād A.D. 828; HoNan IBN IsIIĀk Ah-IBĀDI, who translated from the syriac the works of Ilippocrates, 1)ioscorides, Galen, and Paul of Eigina, and died in 873. IsAac, son of the last-named, and Mobasis his nephew, translated many Greek works into Syriac and Arabic. Acoording to Ibn Juljul, quoted by Abi Usaibiah. the work of Dioseorides on Maleria Medien was translated from the Greek into Arabic by STEPIEx. 
son of Basil, a C'mistian Arab who flomrished at

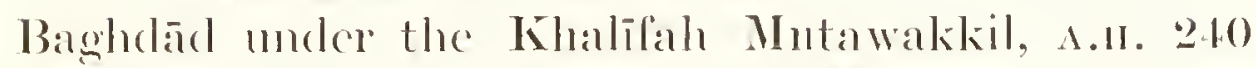
(1.1). 85:3). Ibn Juljul says that Stephen wave the Arabic equivalent for the Greek name of the drug whenever he knew it, and when he did not he transcribed the Greek name into Arabic letters (1)e Sacy, Relation de l'Egypte, Paris, 1810, p. 495). 'The Brit. MIus. MIS. Or. 3366 contains two of the fire books of the work of I)ioscorides (the third and the fomth), and attached to many of the descriptions of the plants are neat coloured drawings (see p. 61).

The greatest botanist produced by the Arabs in the Middle Ages was ABD-ALLAH IBN AL-BAITAR, who was born at Malaga, and died at Damascus A.Il. 646 (A.D. 1248). He travelled extensively in Greece, Hoypt and Asia Minor, and collected a vast amount of botanical knowledge at first hand. He was director of the Medical School of C'airo under Malik al-Kämil (died 12:3\%), and whilst there he compiled the great ARABIC HerBaI. He based his work on the Herbals of Theophrastus, Dioscorides and Galen, and his great knowledge enabled him to correct several mistakes in their works. IIis Ierbal contains the names of nearly soo plants, and he included in it the names of many Persian and Indian drugs (see the translation of J. ron Sontheimer, ¿2 vols. Stuttgart, 187()-72).

Though the Arabs adopted with alacrity Greck medicine and Greck treatment of discase, they never wave up the use of charms and amulets and spells of all kinds. In the time of the IJijrah (June onth. A.1). 620) they belicred, and they still believe, that a few verses of the Isurän, il" written on a paper which is stecped in a bowl of water, will turn the water into a most powerfil merlicine which will hoal the sick 
belicver, and bring disaster and even death upon the unbelicver. 'The man who carrics an agate upon which the really beautiful "Ayāt al-Kursī" or "Throne-verse" is cngraved, is considered to be protected from the attacks of wicked men, and from the assaults of rampires, and the Jinn, and spirits of the night, and the dead who are damned. 


\section{XII}

COPTIC LISTS OF PLANTS

Tue Copts, that is to say, the Egyptians who accepted the teaching of St. Mark in the first century of our era, and embraced Christianity, seem to have escliewed medical seience as taught by the physicians of the famous School of Medicine of Alexandria, and to have been content with the methods of healing employed by their aneestors. No Coptie Book of Medicine laas hitherto been discovered, and the oldest remains of their literature are wholly theological and patristic in character. Egypt was eonquered by the Arabs 4.1). 640, and Nubia twelve years later, and when the Arabs began the work of administering the country they found that the efforts of their governors and officers were hampered by their ignorance of the Coptic language, and the machinery of the Government was worked principally by Copts. In the ninth and tenth centuries the persecution of the Copts by the Arabs began, and for some three centuries the ('hristians in Egypt and Nubia and on the Island of Meroë sulfered greatly. During this period Arab writers began to compose Grammars and Vocabularies of the Coptic language, and many of these are extant in modern manuscripts. (See Rieu, Supplement to the Catulogne of Arabie MSSS. in the British Musemm, No. 4\%, and ('rum, (aldelogute of coptic MSS'., p. 384 [1.) In one of these (Brit. Mus. Orient. 1325) 
We have a ropy of the "Sinala Magna " of Mbü alBal'akāt. commonly known as Ihn Kabl, who died A.1). 1:36:3, and a falesimile of fol. 117 as given on p. s1. In onc section we have a list of trees, a list of vegetables and plants possessing alomatic perfumes, and a list of seeds, both agricultural and medical-in fact, a kind of col'le IIERBAL. The lists are bilingual, coptic and Arabic. The following is a transcript of the Coptic names of plants which are given on p. 81 .

]. Bessi, chrysalocanne, golden seed,

‥ Mat. parsley (for warlands).

3. Krou. carthamus silucestris.

1. Srasos, petrosclimm, rock parsley,

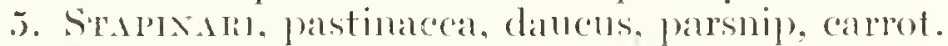

6. Avisi, menthat gentilis.

7. Acs-ox, mentha montana.

8. Amrox, armm (arom), wake-robin. cuckoos-pint.

9. Bissutosil, ruta, rue.

10. EisteTe, ruta montana, wild ruc.

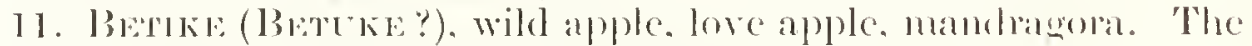

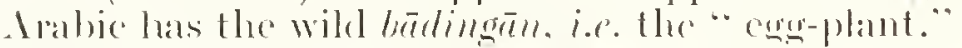

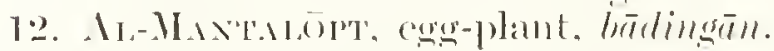

13. IITIT, holus, cathbage, bect, turnip). colcwort.

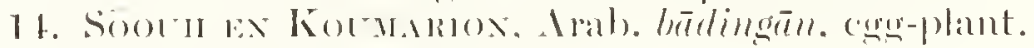

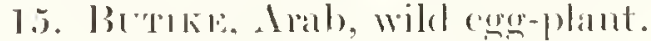

16. Kolocistile, colocynth.

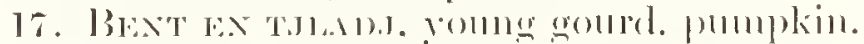

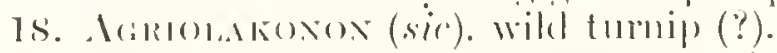

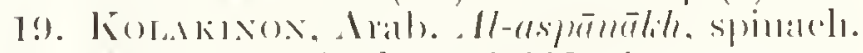

20). Motakin1, Irah, malublingah.

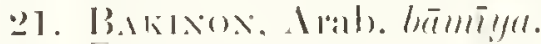

20. () 1: lactucal lettuce.

2.3. Fis.l1, porrtull.

21. Korillk turnip).

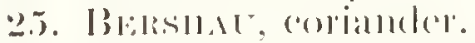

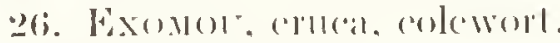

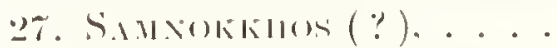

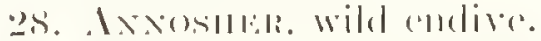

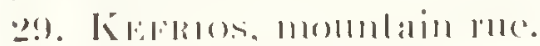

30. Kixos, gatrelen role.

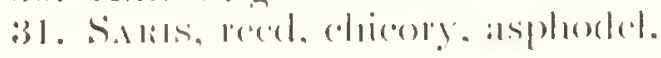




\section{$\overrightarrow{P ! x}$}

In Bepers

गमінx +

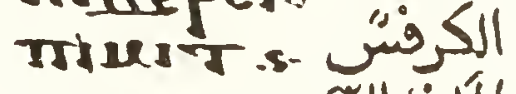

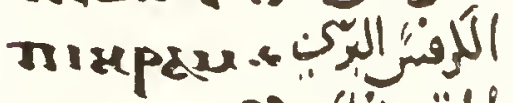

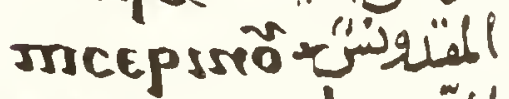

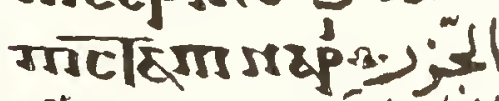

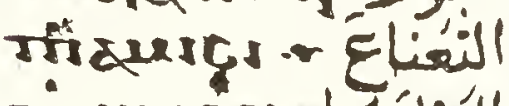
गंड excost

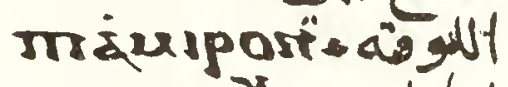
गrasugos

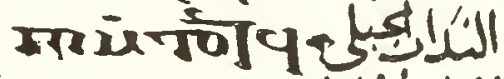

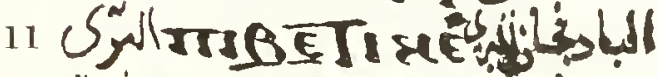

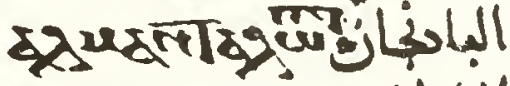

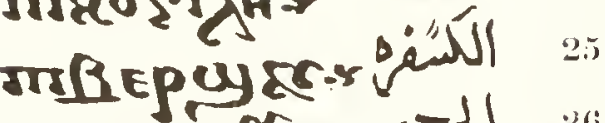

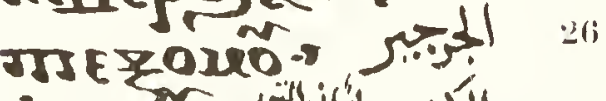
पe

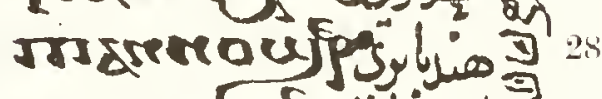
गतर

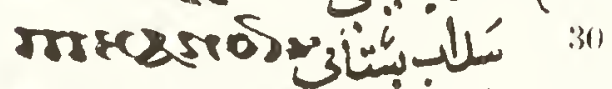

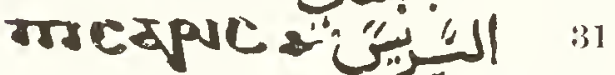
गतस्रुणras 32

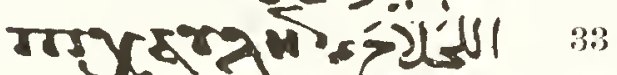

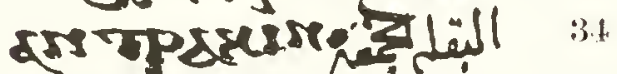
गराpjae क + 35

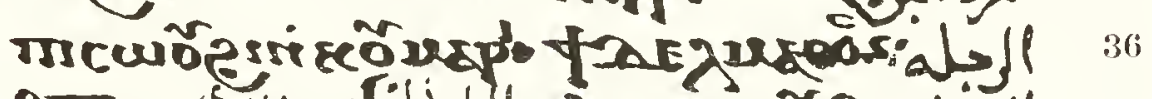
AFroxesul!

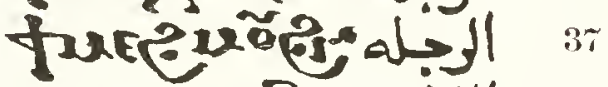
गsжодо का 38

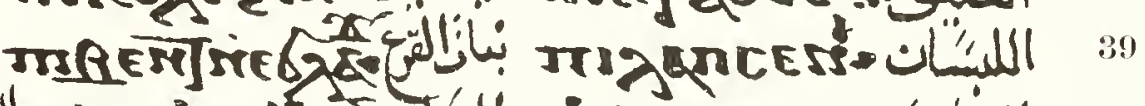

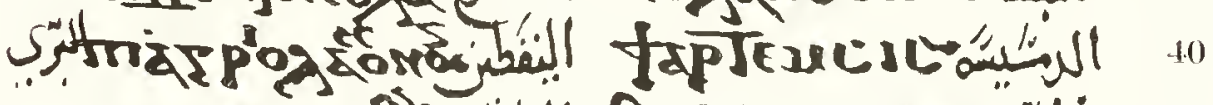

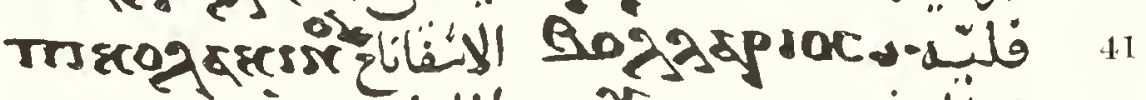

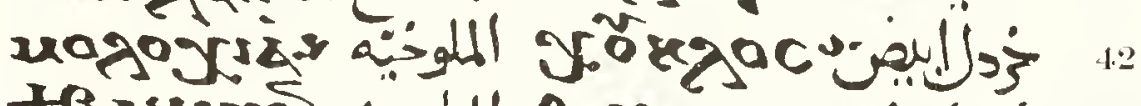
HRatersana गrups: und Borplad...

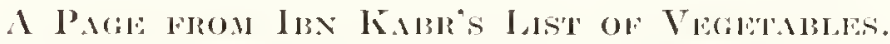
(1rom I3rit. Mus. Ms. Orient. No. 1:3:5, fol. 117a.) 

32. Katoria, mallows.

333. K11.110. . . .

31. MNTRakix, vegetables in general.

35. 'Tlisu, trifolimm. Arab. bursim.

36. Desantios, portulaca, purslain.

3\%. Mensorm, portulaca, purslain.

33. Krostulac. blackberry.

39. IAPsex, drab. libsēn.

10. Antrissis. Artemisia abotonum, southernwood.

4. Bolackios, an Indian (?) regetable.

4.2. Kuorkios, white mustard.

1.3. Borkitus, cuphorbium spurge.

4. Boeratia, enphorbium spurge. 


\section{XIII \\ TIIE ETHIOPIAN (ABYSSINILAN) IIERBB.LL,}

Notuns is known of the means of healing sickness employed by the aboriginal Ethiopians, but we may assume that the "medicine men." of the day had a knowledge of the curative power of water, and were aequainted with the properties of certain plants, both helpful and harmful, and oils. It is possible that a limited knowledge of Egyptian medicine filtered into Ethiopia by way of Nubia, and that the Arabs from Yaman, who invaded the country from the sea about B.C. 1000, may have brought with them the system of medicine which was in use at that time in the neighbouring country of Babylonia. With the coming of the Greek merchants to Adulis and Aksum in the first century of our era came some knowledge of the medical skill of the Alexandrian School, and this was greatly added to when the lithiopians embraced Christianity about A.D. 330. But though the King and the great officials of his Court employed herbdoctors and physicians from the West, the people generally adhered to their beliefs in the native "medicine men." who relied absolutely on spells and charms to effect rures. Christians as well als pagans used spells, only for the names of demons and devils they substituted the names of the Persons of the 'Trinity, the 'Twelve Apostles, the Seren Arehangels, the Four-and-Twenty Priests of hearen, ete. 


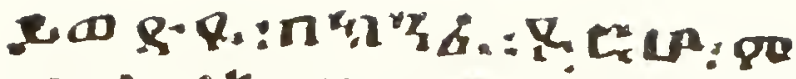

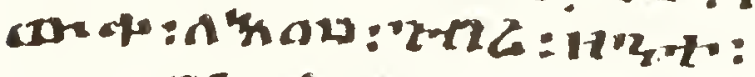

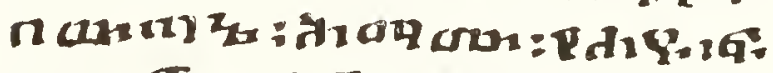

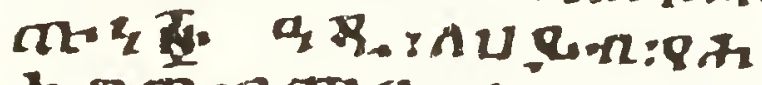

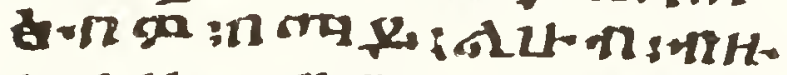

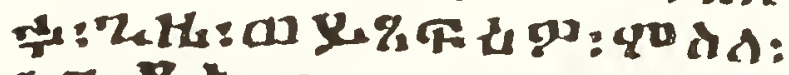

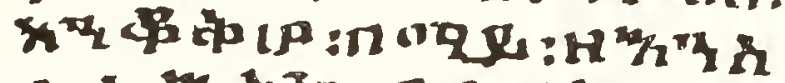

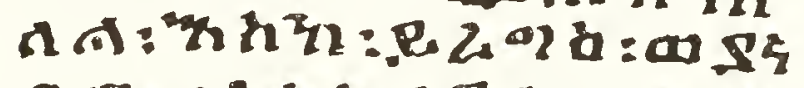

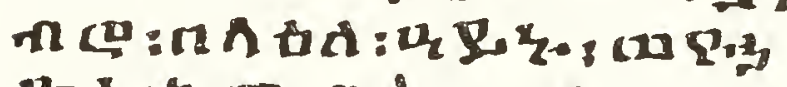

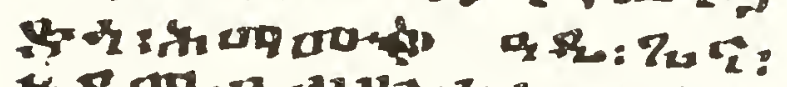

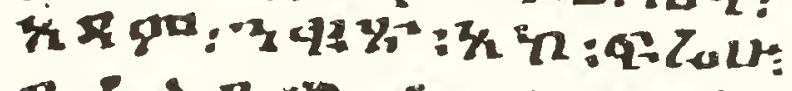

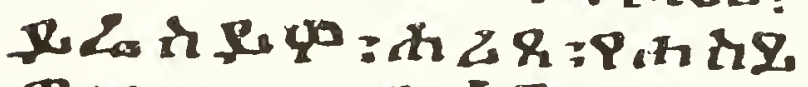
pin on

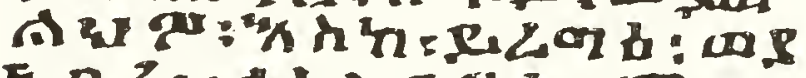

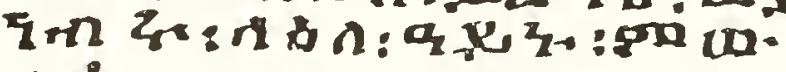
c1: क.

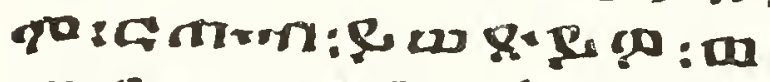

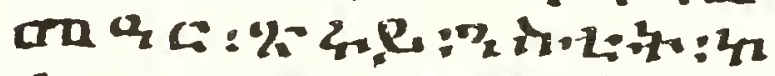

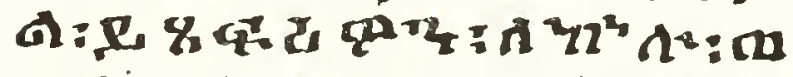

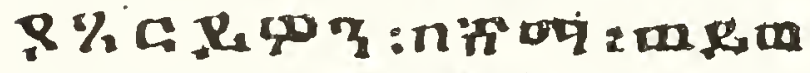

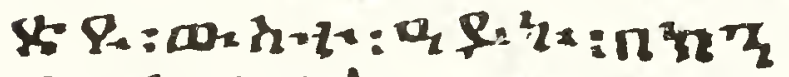

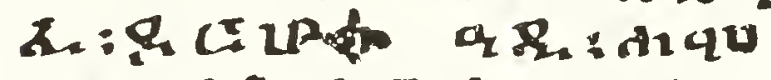

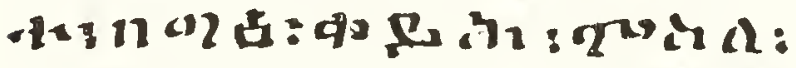

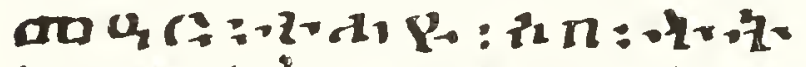

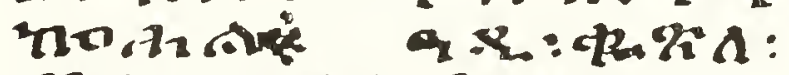

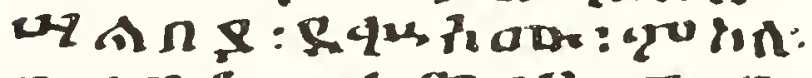

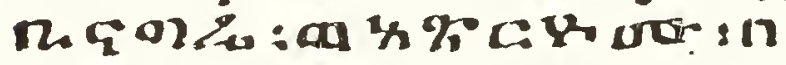

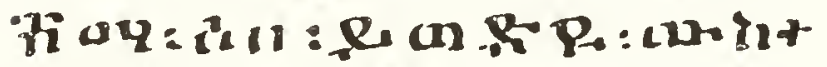

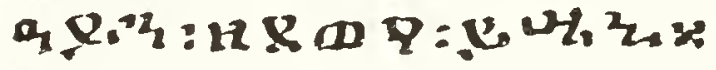

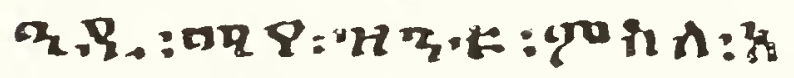

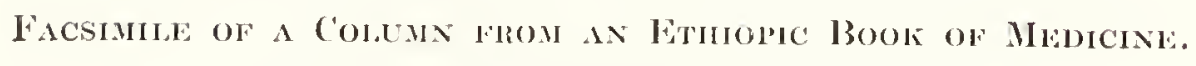

(From Brit. Mus. Add. 207.11, fol. 4b.) 

The native doctors who attended the sick in Ethiopia must, we should think, have had books containing "opies of prescriptions in Ethiopice, but nothing of the kind has yet been discovered, exeept the MS. Adr. 2074 now in the British Museum. 'This little book it contains only 14 folios-is entitled "MAsILAFA FAWEs," and is described as a "Book of healing for every kind of sickness in all the members. They (i.e. the prescriptions) were collected by the ancient wise men so that they miglit be a means of relief for all the sick." "The prescriptions in this book are of a very simple character, and many of them resemble the shorter prescriptions found in the Ebers Papyrus. The first of them deal with the head generally, and then follow receipts for medicines for individual nembers of the body, e.g. the eyes, the ears, the mouth, ete. Most of the sicknesses in Ethiopia are raused by exposure to the extremes of heat and cold, insufficient and improper food, and fever's of all kinds; epilepsy, St. Vitus's dance, dysentery, colic, diarrhoea, cholera, etc. have always been very general in the country. Among women miscarriages and sterility are common.

The British Museum also possesses a large Book of Medicine "Mastiafa MaDHaNit" (Oriental 828) written in Amuaric, that is to say, the modern language of Abyssinia, and in the title it is said that it went forth from Jerusalem. It is about a century old, and it belonged to Walda Giyōrgis Wasan Sagad, King of Shoa, who died in 181\%. 'The actual preseriptions are very short, but many of them are accompanied by long spells and charms which resemble those of the prescriptions of Egypt and Babylonia and Assyria. The Christian in Ethiopia 
often relied lor reliel l'rom his pain on pictures of the Jiruin Mary and the Arohangeds Michact and Gabrict, and little crosses made of wood or bone which were held by him or latid on the sulfering menber or limb.

(On p. s.j will be found a facesimile of a column of Fathiopic text from the manuscript Add. 20\%+1. and it contains sereral prescriptions for rheme in the cyes. ophthahmia, blood in the eyes and defertive sight gencrally. For inflammation, let him bathe the cyes with hot water for a long time. 'Then take extract of the secnted redim plant, which has not flowered, and add thereto fine flour, and rub them down together into a paste. and lay it when moist on the eyes. Or, take the leares of the scented adam plant, macerate them, add run honer, and a little apple, make them all into a firm paste, and dry the eyes, and apply the mixture to them with the feather of a rock. Or. take the gall of a red lamb (or shecp), and honcy. and the patient will find relief if his eyes be smeared with [the mixture]. Or. take the fronds of the shalberya plant, and pound them up with acid (bimagre = vinewar), and dry then with a coth. When these are haid upon the eyes of the sick man he will recover.

The difliculty of transhating the prescriptions in both the Ethiopic and Ambaric Book of Medicine is arcat, becalsise it is well-nigh impossible to identify the drugs. 'The first in modern times to study the botany of Abyssinia was James Bruce, who in his Tracels, Vol. VII, Iandon, 180.). p. 117 fl.. describes a nomber of the most important trees and plants in that country. It was he who macke known to buro-

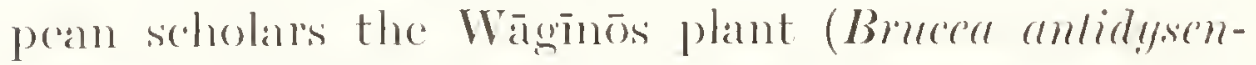
lerica), the bark of which is such a wonderful specific 

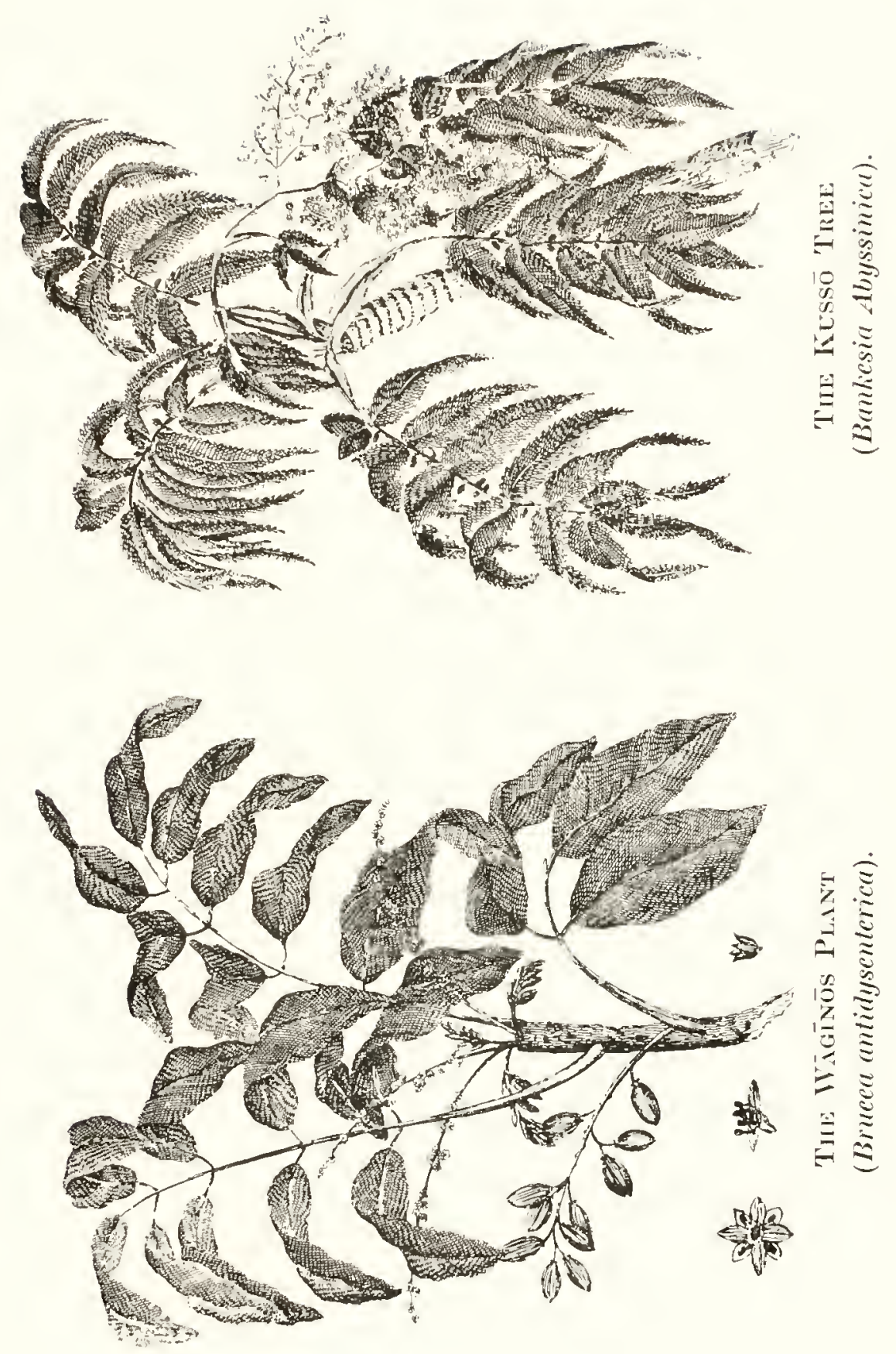

THE WTHOPIN (ABYSSININN) HHRBAL ! for dysentery, and the Kussó (Bankesia Ilyssinica), the flowers of which, heing steeped in water, produce a liquid which is taken by almost every native in order to expel worms from the body. 'The figures of the plant and the tree given on p. 8 s are reproduced from drawings by Bruce. 



\section{INDEX}

A.rox. a magician. vi

Abracadabra. tis

Alū al-Barakīt, so

Adam and bye and wheat. 2I

Esenlapius. an Eeryptian. vii. viii. $11.54 .55 \mathrm{f}$.

Agamede, woman herbalist, 55

Akkadians. I

Al-Baitār. ITerbal of, 77

Alexandria, School of. 57. 58. 84

Alolemy ri, 2

Amid, Sichool of, 70

Anatomy, 27

Anazarba. 6:3

Andreas of Carystus, 57. 64

Anulis, divine Apothecary, 17. 18

Apollo. god of healing. $5 \dot{4}$

Apkallu, the seren, 53

Apsī. 21. 36

Apuleius. L.. Herlal of. 69

Aristotle. Herbal of. 57.73

Asclepidlda, 5.5

Ashipu, exoreist, 51

Asluur. medieal tablets of, 37

Ashmrlanipal. Library of, 37

Asklēpios, 54

Assyrians, medicines of, 43

Astrology, vi

Astronomy, vi

Asu, his treatment, vi. 51

Athothis. herbalist. 10

Arékimesh plant. 61

Babylonians. 1, 27,74

Balkiness. 32

Balsam trees. 2:3

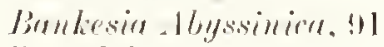

Bar Hebraus. 70. 73

Barmett. I)r. I., 10

Bar-sīwlla, 76

Bïru, the Seren, 元l

Bees. the tears of liit, 24
Bekhten, possessed prineess of. 19

Blood in the eyes. 34

bionli of the leatl. Io

Book of .lledirimes (Sirriae). 73

Bread nsed in medicine. 22

Bogaz koï, medical tablets of. 37

('ensorinus. M. P. ('.. (i7

('harms in medicine. 36

('heimon, herbalist, j4

('hemistry, vi

('hinese, medieal books of, 1

('hin-nong, ?

C'ichorium prescription, 67

Cilicia Campestris, 6.3

Circumcision. oil for, 30

Costiveness, 3:3

('otton trees at Nineveh. 50

Cratenas the herbalist, 58, 64

Crotona, Medieal Sichool of, 50

Culpeper, N., works of, 3,5

Dead, elaim to raise the, 5.5

De Muleria Mestira. 59,61,63

De Maleria Medira (Dioscorides). 6.3

the Simplicibus (Galen), 65

Diachylon plister, 63

Diarrho'id, 3:3

Dieteties, importance of, 66

Dieuches, botanist, 66

Diocles (arystius. 56. 66

Diosentides, Pedannins, faesimile of. 59 ; Arabic and treek llss of his. 5). (61

Discases camsed loy devils. 10. 36;

Divination, Babylonian, 22

Divarlake, IJedical selool of, 70

Draco. Irephalist, 56

Druess, Assyrian, identified, 40.56

Ein. Sumerian Watcr-god. Father of tlac wods. 21, 36 
Ebers Papyrus, preseriptions quoted from or reforred to, 11. 12, 14, 17, $21,30,31,33,37$

Edessa, Medieal Sichool of. 70

Fegptians, medieal books of, 37

limbalmment ehamber, 17

Enlil-bani. 37

Epilepsy, 4

Erasistratus, 64

Ethiopia, medieine in, 54: common discases of. 87; faesimile of Book of Medicine, 85

Euphrates, water of. 50

Exereta of animals and men used in ancient medicines, 27, 74

Eyes, diseases of, 88

Father of the gods, No in Eerpt, lia in Balyylonia, 20, 21

Father of Medicine, 56

Fats of animals and reptiles used in aneient medicine, 32

Fignres, prophylactic, from Ur. 52

Flood, the, 37

Gabriel. Arab herbalist. 78

Gadd. Mr. C. J.. 54

Galen of Pergamus, the "Father of Vedieine." faesimile of Syriae MS. of his the simplicibue, $65,7 \mathrm{l}$

Garden plants, 4!

George, son of Bokht-Īshō, Arab or Persian herbalist. 78

Gerarde, Herbal of, 3

Gesins Petraens, 73

Cilgamish and the plant whieh rejuvenated the old, 50, 5l

(inosties. 18, (is

Gods, the earliest lecrbalists, $1 \mathrm{f}$; the protectors of the limbs, 28

(ionorrlema, 66

Grattarola. Horbal of, 3

(ireat seales of the Juderment, is

Giuller, vase of, viii, lis

(anla, laiser of the deitl. 18, :36

(Ainclli sĩ̄bhor, Nedieal school of, 70

Gymnasties, importance of, 600

llair-Wisl of (pheen shesh, 3:2

Hall of Osiris, 18

Hathor and drugered beer. Is

Heka (Egy]tian magic), 14
Helen and opiom, ns

Henna plant. 31

Heraklicles, 56

llerbal, the Abyssinian. 84

Herbal, the Arabice of Al-Baitĩr. 77

Herbal, the Assyrian (bilingual). $38 \mathrm{f}$. : extruct from. 41

Herbal, the Coptie, 79: faesimile. 81

Herbal, the Greek, 54 f., 57, 6:3

Herbal, the Latin, 67

Herbal, Plinv's, 67

Herlual, the Sinmerian, 37

Herbal. the Syriac, 70, 71

Herbalist. old shop deseribed, is ff.; modern methods of the. $8 \mathrm{f}$.

Herbarimm of Apuleius, 69

Herb doctors. 5is

Herb-garden, Nerodach-Baladan II, 45,47

Herbs. Chinese. 9; of Khatti, 50

Herophilus, 57

Hippoerates, 27, 56, 64

Historia planlarmm, 57

Hittites, medical tablets of, 37

Holy oil (Mérón), 23; and see Oil.

Honain ibn Ishāk, Arab herbalist. 76

Honey, of divine origin, 25; honey and oil, 31

Horus, 12, 13, 14

Hospitals in temples, 58

Huang-ti, Chinese herbalist.9

Hygieia, viii, 55

Imhetep, herbalist and physician, II lneantations, 2, 36, 53

Ineense, of divine origin, 24

Indians, medical books of. 10

Influenza, It

Ionie School of Medieine. 50

Isaae, Arab herbalist. 7 (i

Isis raises (Koiris from the dead, 12, I3

Jickal-god (Amubis), IS

. lesis, the Amointed One, 30

Mulian the Apestate. 60

- Juliana Anieia, codex of. (63)

Kiluepera, the ('reator, 20

Khonsu, the alienist gud. Is

Kummu (templo hospital), 52

Kinssó tree, 8!)

Kyphi ineerse, 30 
Tolserpitium. 59

lovel, Mrs. ('. l', viii

lij)-stick. 31

lists of Plants, see Herbal.

Manl plant and immortality. 12

Mlagie, 2

Manctlo. 10

Mankind, destruetion of. 18

Marduk-shumiddin, herb list of. 49

Medicine, Egyptian, 10; Oricntal, $56,84,85,87$

Medieine and magic, $\mathrm{v}$

lledicines, of clivine origin, I

1l'̄mes. 10

Menecrates, T. C.. 63

Mercurius Pragmalicus, 3

Merodach-Batadan II, 45, 47, 49

Mliscarriage. 87

Mithridates I'I Eupator, herbalist, 58

Mnesisthens, 66

Moutl, gangrene of, 75

Mummification. 27

Mummy, tincture of, 5

Murm plants, 50

Närmer-men, 10

Närt tree. the divine. 24

Nestorian herbalists, 76

Niger (Sextius), 58, 64

Nikander, 64

Ninazu, lord of physicians, vii. 15, 36

Nineveh, medical tablets at, 37; fall of. 54

Ningishzida, 15, 17

Ninkhursag. 30

Ninurta, 1s, 36

Nisibis, Mledical School of, 76

Nu. Water-god. Father of the gods, 20

Nubia, medieine in, 54

Oil, the holy. 29: perfumed, 31

(bil of ecdar, divine, 24

Gintments, perfomed and medicaterd. 31

( trihasus of Pergamus, (i4

Osiris. 12; blood of. 24; cmbalmed and resnrrected, 17: controls river of heirs'n, 20

Pamplnilus, 58, 6:3
Paneration, 67

Papyri, modieal, 26;

Papvrus, magical, 24; Edwin Siniths, vi

Panl of Agina, 76

Persia, medicine in, 54

Phacnarete, midwife, 56

Pharaoh's scrpents, 7

Philumenus. $66^{\circ}$

Physie gardens, 4!)

Pliysicians, Greek, Nestorian and Áral, 70,76

Physiology, 27

Plant of rejuvenation, 50

Plants. lists of. $v$, and see Herbal; divine merlieal, 24

Pliny, Herbal of, 57, 58, 67

Porlislirius. 55

Poison, 58

Polydamna, woman herbalist, 55.5

Preseriptions, 4. 5. 17, 33-35

Priseianus. 'T.. Herbal of. 68

Ptah, plants from, 24

Pumice-stone. 32

Pythagoras, 56

Rā, poisoned by Isis, 12, 13, 20, 28

Rod, the herbalists', vi; of Ningishzicla. 11

Rolrde, Mliss E. S., viii

Salves, 31

Samonicus, Q. S., 68

Sapor I, 70

Semti. Book of Medieine of, 17

Sennacherib planter of cotton, 50

Sent. Book of Medicine of, 17

Serorins of Rish Ainā. 73

Serpent stalf. 5.)

Set, blood of, 24; and of disease and death, 12, 14

Shamash, Whent god, 22

Slin and 'lefnut and ineense plants. 24

Shurippak, 37

Silphimm, 43

Sin. a Whent god. 22

Singer, Mr. ( .., 58, 63.3

Simitl, Mr. Nidney, 5.3

Sorcery in modicine, 38

Sipells in modicine, 10, 30

Stephen, trinslator, 77

Sumerians, 1, 37 
Sun-stone, plants from. 24

sun-woll at Holiopolis. 2:2

syphilis, dio

'Trheser, King. II

Thales. 56 i

Theophrast as of liresus, his list of Plants. 57.64

Thessalus, 56

Thompson. 1)r. ('ampleell, 3!) f.

Thoth, heart of Ris. thrice great, 13. $14,17,28$

'Throat, preseriptions for. 74

Tilerius. Emperor. (i.3

Tootlache caused by a worm. 44

Treatment, medical, in Babvlon. 5l

T'uat. I2

Turner. his New Ilerball, 3 [ngurnts. medieated, 20

En-nefer. herbalist, 56

[r. it livphallic figures from, 5:

Vivisection, 70

Wägons plant. ss

Wasan Silgatl. his Book of Medieine, 87

Water as a merlicine. 36: a divine mement. $20 \mathrm{f}$ : of life, 201 ; turned to blonel, vi

Wheat plant. $21 \mathrm{f}$.

Wine and oil, :-9!)

Wisdom, natural. I2

Woollory, .1/r. ('. L.. his discoverios. 53

\%eno, 60.73 



